\title{
EL INCIERTO FUTURO DE LA LIBERTAD DE EXPRESIÓN EN EL SISTEMA INTERAMERICANO DE DERECHOS HUMANOS
}

\author{
THE UNCERTAIN FUTURE OF FREEDOM OF EXPRESSION UNDER \\ THE INTERAMERICAN SYSTEM OF HUMAN RIGHTS
}

\author{
Max Silva Abвotт*
}

\begin{abstract}
RESUMEN: En razón de su importancia esencial para la democracia, la libertad de expresión se encuentra fuertemente protegida dentro del sistema interamericano de derechos humanos, tanto por diversos documentos como por la jurisprudencia constante de la Corte. Sin embargo, esta situación podría cambiar bastante con motivo de la Convención Interamericana contra toda Forma de Discriminación e Intolerancia, en atención a las medidas que ella contempla para prevenir actos de esta especie.
\end{abstract}

Palabras clave: Libertad de expresión, Discriminación, Intolerancia, Corte Interamericana, Deber de prevenir.

ABSTRACT: Due to its utmost importance for democracy, freedom of expression is strongly protected within the inter-american system of human rights, as much in many of its documents as in the constant jurisprudence of the Court. This situation, nevertheless, might change quite a bit with the Inter-American Convention Against All Forms of Discrimination and Intolerance, in connection with the measures that the convention establishes to prevent such actions.

Key words: Freedom of expression, Discrimination, Intolerance, Inter-American Court, Duty of Prevention.

\section{INTRODUCCIÓN}

Tradicionalmente se ha entendido que dentro del conjunto de los derechos humanos que protege el sistema interamericano, la libertad de expresión posee un papel esencial, al ser una pieza clave para el funcionamiento de la democracia.

Con todo, y a pesar que diversos documentos regionales y la jurisprudencia desarrollada por la Corte la tutelan de manera contundente, este derecho podría debilitarse bastante en el futuro, de entrar en vigor la reciente Convención Interamericana contra toda Forma de Discriminación e Intolerancia, debido a las amplias facultades que ella otorga al Estado a fin de prevenir actos de esta especie.

\footnotetext{
Doctor en Derecho por la Universidad de Navarra. Profesor de Filosofía del Derecho de la Facultad de Derecho, sede Concepción, Universidad San Sebastián, Chile. Dirección Postal: Lientur 1457, Concepción. Correo electrónico: max.silva@uss.cl. Este proyecto ha sido financiado por la Dirección General de Investigación de la Universidad San Sebastián, Proyecto DIUSS No 2013-0024-I.
} 
De ahí que el objetivo principal del presente trabajo sea indagar si son compatibles esos documentos y jurisprudencia con la convención mencionada. Desde ya debe advertirse que dicha compatibilidad resulta bastante discutible. También se indagará de qué manera podría verse afectada la libertad de expresión con motivo de lo anterior, así como parte de la evolución que ha sufrido la jurisprudencia de la Corte a su respecto.

Para ello, primero se estudiarán los principales documentos del sistema interamericano que protegen la libertad de expresión, así como la jurisprudencia de la Corte atingente al tema y su evolución. Luego, se hará un comentario crítico de la convención contra la discriminación y la intolerancia. Finalmente, se analizará la compatibilidad entre ambas normativas y se comentarán algunas de las consecuencias que lo anterior podría originar para la libertad de expresión.

\section{LOS DOCUMENTOS FUNDAMENTALES QUE PROTEGEN LA LIBERTAD DE EXPRESIÓN}

Un rápido vistazo a nuestros documentos internacionales regionales muestra muy a las claras que la libertad de expresión es un aspecto fundamental del sistema interamericano de derechos humanos. En atención a que este derecho posee importancia dispar en unos y otros instrumentos, se expondrá primero lo que señalan los documentos menos específicos a este respecto en un epígrafe común, para terminar con aquellos que lo abordan de forma más detallada en epígrafes independientes. Debe advertirse que este orden expositivo en nada se relaciona con la importancia jerárquica de cada uno de estos instrumentos.

\subsection{DOCumentos Varios}

Dentro de los documentos que tratan esta materia de forma más bien tangencial, tenemos en primer lugar, la Declaración Americana de Derechos y Deberes del Hombre, de 1948, la cual señala en su Artículo IV: "Toda persona tiene derecho a la libertad de investigación, de opinión y de expresión y difusión del pensamiento por cualquier medio".

Luego, ahondando más en esta cuestión, la Convención Americana de Derechos Humanos, de 1969 (y que entró en vigor en 1978), declara en su art. 13, relativo a la libertad de pensamiento y de expresión: "1. Toda persona tiene derecho a la libertad de pensamiento y de expresión. Este derecho comprende la libertad de buscar, recibir y difundir informaciones e ideas de toda índole, sin consideración de fronteras, ya sea oralmente, por escrito o en forma impresa o artística, o por cualquier otro procedimiento de su elección. 2. El ejercicio del derecho previsto en el inciso precedente no puede estar sujeto a previa censura sino a responsabilidades ulteriores, las que deben estar expresamente fijadas por la ley y ser necesarias para asegurar: a) el respeto a los derechos o la reputación de los demás, o b) la protección de la seguridad nacional, el orden público o la salud o la moral públicas. 3. No se puede restringir el derecho de expresión por vías o medios indirectos, tales como el abuso de controles oficiales o particulares de papel para periódicos, de frecuencias radioeléctricas, o de enseres y aparatos usados en la difusión de información o por cualesquiera otros medios encaminados a impedir la comunicación y la circulación de ideas y opiniones. 4. Los espectáculos públicos pueden ser sometidos por la ley a censura previa con el exclusivo 
objeto de regular el acceso a ellos para la protección moral de la infancia y la adolescencia, sin perjuicio de lo establecido en el inciso 2. 5. Estará prohibida por la ley toda propaganda en favor de la guerra y toda apología del odio nacional, racial o religioso que constituyan incitaciones a la violencia o cualquier otra acción ilegal similar contra cualquier persona o grupo de personas, por ningún motivo, inclusive los de raza, color, religión, idioma u origen nacional".

Por su parte, el Protocolo Adicional a la Convención Americana Sobre Derechos Humanos en materia de Derechos Económicos, Sociales y Culturales, conocido como "Protocolo de San Salvador", de 1988 (y que entró en vigor el 1999), señala en su art. 14.3, referido al derecho a los beneficios de la cultura, que "Los Estados partes en el presente Protocolo se comprometen a respetar la indispensable libertad para la investigación científica y para la actividad creadora”.

La Carta Democrática Interamericana de 2001, dice en su art. 4: "Son componentes fundamentales del ejercicio de la democracia [...] la libertad de expresión y de prensa”.

Finalmente, la Carta Social de Las Américas, aprobada en sesión plenaria de la OEA en 2012, al referirse a las actividades artísticas y culturales, expresa en su art. 30: "Es necesario y pertinente que los Estados Miembros generen y garanticen un entorno propicio para la libertad de pensamiento, expresión e información, así como las condiciones que faciliten la expresión creativa y fomenten la investigación e imaginación en un ambiente de tolerancia”.

Corresponde ahora analizar someramente los documentos que aluden con más detalle a la libertad de expresión, partiendo por los más recientes.

\subsection{La Declaración de Principios Sobre la Libertad de Expresión}

En primer lugar, es necesario referirse a la Declaración de Principios Sobre Libertad de Expresión, adoptada por la Comisión Interamericana de Derechos Humanos en el año 2000, la cual denota una clara postura en pro de la libertad de expresión, en detrimento de otras situaciones y derechos que podrían colisionar con ella.

En su Preámbulo señala que "la consolidación y desarrollo de la democracia depende de la existencia de libertad de expresión" (párr. 2), razón por la cual "cuando se obstaculiza el libre debate de ideas y opiniones se limita la libertad de expresión y el efectivo desarrollo del proceso democrático" (párr. 4). Por eso, este derecho es fundamental para conseguir "una mayor transparencia de los actos del gobierno afianzando las instituciones democráticas" (párr. 5). Luego de hacer alusiones a documentos universales y regionales que consagran este derecho (párr. 6, 7 y 8) señala de manera perentoria que este derecho "comprende la libertad de buscar, recibir y difundir informaciones e ideas sin consideración de fronteras y por cualquier medio de transmisión" (párr. 8). De hecho, lo considera tan esencial para el desarrollo de los derechos humanos, que en su momento se creó la "Relatoría para la Libertad de Expresión, como instrumento fundamental para la protección de este derecho en el hemisferio" (párr. 9) ${ }^{1}$, pues esta Declaración se adoptó, precisamente, debido a la impor-

1 La Relatoría Especial fue creada por la Comisión Interamericana de Derechos Humanos en octubre de 1997, durante su $97^{\circ}$ Período de Sesiones. Al año siguiente, durante la Segunda Cumbre de las Américas, los Jefes de 
tancia fundamental que tiene la libertad de prensa para el funcionamiento de la democracia representativa y para que se proteja efectivamente este derecho (párr. 13).

La Declaración establece varios principios. Entre otros, que la libertad de expresión es un derecho inalienable y fundamental para la existencia de una sociedad democrática (No 1), razón por la cual toda persona tiene derecho a "buscar, recibir y difundir información y opiniones libremente", aludiendo expresamente al art. 13 de la Convención Americana (No 2). Todo esto explica que "5. La censura previa, interferencia o presión directa o indirecta sobre cualquier expresión, opinión o información difundida a través de cualquier medio de comunicación oral, escrito, artístico, visual o electrónico, debe estar prohibida por la ley. Las restricciones en la circulación libre de ideas y opiniones, como así también la imposición arbitraria de información y la creación de obstáculos al libre flujo informativo, violan el derecho a la libertad de expresión". Es por eso que se prohíbe la colegiación obligatoria o la tenencia de títulos para ejercer el periodismo (No 6). Por iguales razones, se opone a los condicionamientos previos para ejercer este derecho (principio 7) y prohíbe toda intimidación o amenaza a los comunicadores sociales, debiendo el Estado prevenirlas, investigarlas y sancionarlas (No 9).

Por otro lado, el acceso a la información que se encuentre en manos del Estado es un derecho fundamental, solo restringible de forma excepcional y únicamente por una ley previa, fundamentada además, en razones de seguridad nacional para el régimen democrático (No 4). Por eso los funcionarios públicos estarán sujetos a un mayor escrutinio, no siendo aplicables a su respecto las leyes de desacato (No 11). Análogos argumentos explican que las leyes de privacidad no deban inhibir o restringir la investigación o difusión de información de interés público, y que solo quepa establecer sanciones civiles, y no penales, para proteger la reputación de los funcionarios públicos, de personas públicas o de particulares que se hayan involucrado voluntariamente en asuntos de interés público. Por último, se debe probar que hubo intención de infringir daño por parte del comunicador, su pleno conocimiento de estar difundiendo noticias falsas, o una grave negligencia suya en la indagación acerca de su verdad o falsedad (No 10).

Finalmente, se prohíben los monopolios u oligopolios en la propiedad o control de los medios de comunicación (No 12) y se condena toda forma de presión o premio del Estado a los comunicadores en función de sus líneas informativas, pues su labor debe ser independiente de los intereses de la autoridad ( $\mathrm{N}^{\circ} 13$ ).

Estado y de Gobierno reconocieron el papel fundamental que tiene el derecho a la libertad de pensamiento y de expresión, y manifestaron su satisfacción por la creación de la Relatoría Especial. En la Declaración de Santiago expresaron: "Coincidimos en que una prensa libre desempeña un papel fundamental [para la defensa de los derechos humanos] y reafirmamos la importancia de garantizar la libertad de expresión, de información y de opinión. Celebramos la reciente constitución de un Relator Especial para la Libertad de Expresión, en el marco de la Organización de los Estados Americanos". ("Declaración de Santiago. Segunda Cumbre de las Américas. 18-19 de abril de 1998”. Santiago, Chile. En: Documentos Oficiales del Proceso de Cumbres de Miami a Santiago, Volumen I. Oficina de Seguimiento de Cumbres. OEA. Disponible en http://www.oas.org/es/cidh/expresion/showarticle. asp?artID=52\&lID=2 [Fecha de consulta: 11 de septiembre de 2014]. 


\subsection{La Declaración de Chapultepec}

Pese a su carácter no vinculante, también vale la pena mencionar la Declaración de Chapultepec, adoptada en la Conferencia Hemisférica sobre Libertad de Expresión, en México D. F., el 11 de marzo de 1994. Contiene un Preámbulo y 10 principios.

Comienza señalando que ella busca afianzar el sistema democrático en el continente ante las amenazas que lo ponen en peligro (Preámbulo, párr. 1 y 2). Es por eso que el binomio libertad-democracia resulta fundamental (párr. 4), razón por la cual "La libertad no debe ser coartada en función de ningún otro fin" (párr. 5). De ahí que sus aspectos esenciales sean la libertad de expresión y de prensa (párr. 6 y 9 y, más adelante, el principio No 1), siendo por ello la libertad de expresión el "motor y punto de partida de los derechos básicos del ser humano" (párr. 7).

El párrafo 8 de su Preámbulo es importante al declarar: "Solo mediante la libre expresión y circulación de ideas, la búsqueda y difusión de informaciones, la posibilidad de indagar y cuestionar, de exponer y reaccionar, de coincidir y discrepar, de dialogar y confrontar, de publicar y transmitir, es posible mantener una sociedad libre. [...] Por esto, rechazamos con vehemencia a quienes postulan que libertad y progreso, libertad y orden, libertad y estabilidad, libertad y justicia, libertad y gobernabilidad, son valores contrapuestos". De ahí que "La tentación del control y de la regulación coaccionante ha conducido a decisiones que limitan la acción independiente de los medios de prensa, periodistas y ciudadanos que desean buscar y difundir informaciones y opiniones" (párr. 14). Por eso aboga por la libertad de los medios de comunicación (párr. 10, 11 y 12).

Con posterioridad, y dentro de los Principios que establece, destacan: el derecho a buscar y recibir información, expresar opiniones y divulgadas libremente (No 2); la condena las presiones de cualquier tipo que atenten contra la libertad de expresión y de prensa (No 4); la condena de la censura previa y de cualquier imposición u obstáculo a la divulgación de los mensajes (No 5); así como la colegiación obligatoria de periodistas (No 8).

\subsection{La Opinión Consultiva OC 5/85 de la Corte Interamericana}

Por último, y como corolario, mención aparte merece la importante y conocida Opinión Consultiva OC-5/85 de la Corte Interamericana, de 13 de noviembre de 1985, titulada "La colegiación obligatoria de Periodistas", solicitada por el gobierno de Costa Rica, que trata directamente la libertad de expresión.

Como advertencia previa, y en armonía con los demás instrumentos internacionales vistos, se constata sin mayor dificultad que "las garantías de la libertad de expresión contenidas en la Convención Americana fueron diseñadas para ser las más generosas y para reducir al minimum las restricciones a la libre circulación de las ideas" (párr. 50).

De hecho, se percibe claramente la clave metodológica del análisis que la Corte hace del artículo 13 es el principio pro homine ${ }^{2}$, a fin de restringir lo menos posible este dere-

\footnotetext{
2 Sobre el principio pro homine, Ferrer Mac-Gregor (2011) pp. 340-358, 361-366 y 387-390; AmaYa (2005) pp. 337-380; CANÇAdo (2006) pp. 310-313; Nogueira (2012c) pp. 1176-1178 y 1187-1189; Nogueira (2012a) pp. 153-154 y 158-161.
} 
cho. Por eso al comparar esta normativa con otros tratados ${ }^{3}$, considere que "tal método no podría emplearse nunca para incorporar a la Convención criterios restrictivos que no se desprendan directamente de su texto, por más que estén presentes en cualquier otro tratado internacional” (párr. 51), precisamente en razón del art. 29, en virtud del cual debe primar siempre la norma más favorable para este derecho (párr. 52).

Debe tenerse en cuenta que el principio pro homine, en razón de ser un criterio material o de contenido, primaría, para la Corte, sobre otros criterios de tipo formal, como podría ser el de jerarquía ${ }^{4}$, o también -creemos- el de especialidad, es decir sobre tratados más importantes o más específicos, respectivamente, que la Convención Americana.

Ahora bien, luego de analizar los antecedentes que dieran origen a la OC-5/85, la Corte señala: "quienes están bajo la protección de la Convención tienen no solo el derecho y la libertad de expresar su propio pensamiento, sino también el derecho y la libertad de buscar, recibir y difundir informaciones e ideas de toda índole. Por tanto, cuando se restringe ilegalmente la libertad de expresión de un individuo, no solo es el derecho de ese individuo el que está siendo violado, sino también el derecho de todos a 'recibir' informaciones e ideas, de donde resulta que el derecho protegido por el artículo 13 tiene un alcance y un carácter especiales. Se ponen así de manifiesto las dos dimensiones de la libertad de expresión. En efecto, esta requiere, por un lado, que nadie sea arbitrariamente menoscabado o impedido de manifestar su propio pensamiento y representa, por tanto, un derecho de cada individuo; pero implica también, por otro, un derecho colectivo a recibir cualquier información y a conocer la expresión del pensamiento ajeno" (párr. 30). Por eso, en virtud de esta doble dimensión, individual y colectiva (párr. 75), estos dos derechos son indivisibles, de modo que una restricción de las posibilidades de divulgación representa directamente, y en la misma medida, un límite al derecho de expresarse libremente” (párr. 31).

En su dimensión individual, la libertad de expresión implica la posibilidad de emplear cualquier medio apropiado para difundir el pensamiento y hacerlo llegar a otros (párr. 31). En su dimensión social, ella resulta fundamental para el intercambio de ideas e informaciones, comprendiendo tanto el derecho de comunicar o difundir las ideas propias, como de conocer opiniones y noticas ajenas (párr. 32), razón por la cual ambas dimensiones deben ser garantizadas simultáneamente (párr. 33).

Lo anterior explica que de forma reiterada se prohíba la censura previa (párr. 29, 33, 35, 38, 54, y sin mencionarla con ese nombre, en los párr. 39 y 77), "la cual es siempre incompatible con la plena vigencia de los derechos enumerados por el artículo 13. [...] En esta materia toda medida preventiva significa, inevitablemente, el menoscabo de la libertad garantizada por la Convención" (párr. 38). Por eso señala de forma perentoria: "Un sistema de control al derecho de expresión en nombre de una supuesta garantía de la corrección y veracidad de la información que la sociedad recibe puede ser fuente de grandes abusos y, en el fondo, viola el derecho a la información que tiene esa misma sociedad" (párr. 77). La

3 La Corte compara la Convención Americana con la Convención Europea para la Protección de los Derechos Humanos y de las Libertades Fundamentales (artículo 10) y el Pacto Internacional de Derechos Civiles y Políticos (artículo 19), concluyendo que el primero otorga una protección más amplia para este derecho (párr. 50).

4 Castilla (2011) pp. 149-153; Caballero Ochoa (2011) pp. 109-112 y 128; Nogueira (2012c) pp. 1202 1203 y 1218. 
única excepción que se permite es la censura previa de espectáculos públicos para la protección moral de la infancia y la adolescencia (párr. 29 y 38).

Todo lo dicho hasta aquí explica que se prohíban los monopolios u oligopolios, sean públicos o privados (párr. 33, 34 y 56), y también que se aluda a los 'medios indirectos' que atentan contra la libertad de expresión (párr. 29, 47 y 48).

Debe recordarse que la razón de esta férrea defensa de la libertad de expresión radica en su vínculo fundamental con la democracia (párr. 41-45, 54, 69, 70 y 76), aspecto que incluso le sirve como herramienta para la propia interpretación de la Convención (párr. 44). "La libertad de expresión es una piedra angular en la existencia misma de una sociedad democrática. Es indispensable para la formación de la opinión pública. Es también conditio sine qua non para que los partidos políticos, los sindicatos, las sociedades científicas y culturales, y en general, quienes deseen influir sobre la colectividad puedan desarrollarse plenamente. Es, en fin, condición para que la comunidad, a la hora de ejercer sus opciones, esté suficientemente informada. Por ende, es posible afirmar que una sociedad que no está bien informada no es plenamente libre" (párr. 70), siendo el periodismo su manifestación primaria y principal (párr. 70). Por eso "el bien común reclama la máxima posibilidad de información y es el pleno ejercicio del derecho a la expresión lo que la favorece” (párr. 77).

De ahí que la Corte sea clara al expresar su total repudio a la intervención de la autoridad a fin de limitar este derecho a priori, como son "la censura previa, el secuestro o la prohibición de publicaciones y, en general, todos aquellos procedimientos que condicionan la expresión o la difusión de información al control gubernamental. En tal hipótesis, hay una violación radical tanto del derecho de cada persona a expresarse como del derecho de todos a estar bien informados, de modo que se afecta una de las condiciones básicas de una sociedad democrática" (párr. 54). Por eso también contraviene la Convención "todo acto del poder público que implique una restricción al derecho de buscar, recibir y difundir informaciones e ideas, en mayor medida o por medios distintos de los autorizados por la misma Convención; y todo ello con independencia de si esas restricciones aprovechan o no al gobierno" (párr. 55).

Ahora bien, teniendo lo antes dicho como telón de fondo, al referirse al tema que diera origen a la OC-5/85 (la colegiatura obligatoria que se exigía a los periodistas en Costa Rica), y en atención al papel fundamental que tienen estos comunicadores sociales para una sociedad democrática, señala la Corte que no puede haber individuos o grupos que a priori estén excluidos para acceder a los medios de comunicación (párr. 34). Por eso, pese a dejar en claro las ventajas de la colegiación en algunas profesiones, tanto aceptando algunos de los argumentos presentados por los solicitantes (párr. 60-62) como, según su entender, por razones de orden público o de bien común (párr. 63-68), considera que la colegiación obligatoria es incompatible con la libertad de expresión (párr. 58 y 72-81), sin perjuicio que lo anterior significaría cerrar a la sociedad posibles fuentes de información (párr. 75). Todo lo dicho, en virtud de la indivisible doble dimensión -individual y colectiva-, de la libertad de expresión, según declaraba en los párr. 30-33.

De esta manera, vinculando todo lo dicho hasta aquí, para la Corte la misma idea de orden público exige otorgar las mayores garantías a la libre circulación de noticias, ideas y opiniones, así como el más amplio acceso a la información por parte de todos. Ello, puesto 
que "La libertad de expresión se inserta en el orden público primario y radical de la democracia, que no es concebible sin el debate libre y sin que la disidencia tenga pleno derecho de manifestarse" (párr. 69).

Empero, lo anterior no significa, que la libertad de expresión sea un derecho absoluto, en virtud del art. 13.2 de la Convención, que protege los derechos o reputación de los demás, así como la seguridad nacional, el orden público o la salud o la moral públicas. De ahí que pese a su clara defensa de este derecho, señale que no todas las restricciones a los medios de comunicación violan la libertad de expresión (párr. 35, 55 y 57), pues caben causales de responsabilidad posterior (y solo posterior) por el abuso de esta libertad (párr. 35 y 36), en particular, las contempladas en el art. 32.2 de la Convención Americana: "Los derechos de cada persona están limitados por los derechos de los demás, por la seguridad de todos y por las justas exigencias del bien común, en una sociedad democrática” (párr. 41).

Sin embargo, estas restricciones poseen varios requisitos de forma (párr. 37-40): que las posibles causales sean establecidas por la ley (párr. 40); que se establezca de manera previa, en razón de fines legítimos y siempre que dichas restricciones sean necesarias para conseguirlos -y no simplemente "útiles", como señalan el párr. 46 y especialmente el párr. 79- (párr. 39); y que sean dictadas de forma "expresa y taxativa" (párr. 39 y 40). Además, siguiendo las pautas del Tribunal Europeo y el principio pro homine, desde una perspectiva de fondo, debe usarse la alternativa que en menor medida restrinja el derecho: "para que sean compatibles con la Convención las restricciones deben justificarse según objetivos colectivos que, por su importancia, preponderen claramente sobre la necesidad social del pleno goce del derecho que el artículo 13 garantiza y no limiten más de lo estrictamente necesario el derecho proclamado en el artículo 13" (párr. 46).

Finalmente, todo lo antes expuesto fue lo que llevó a la condena de la exigencia de la colegiatura obligatoria de periodistas, como establecía la Ley Orgánica del Colegio de Periodistas de Costa Rica, No 4420, de 1969.

\section{LA JURISPRUDENCIA DE LA CORTE INTERAMERICANA ATINGENTE AL TEMA}

De manera congruente con lo sostenido por ella misma en la $O C-5 / 85$, la Corte considera que la libertad de expresión tiene una importancia fundamental, al comprender el derecho de emitir y recibir información e ideas de toda índole ${ }^{5}$. Es por eso que posee una dimensión individual y una dimensión social. La individual consiste en no ser menoscabado en las prerrogativas que este derecho confiere ${ }^{6}$, lo cual incluye el derecho a escribir y además,

\footnotetext{
5 Caso "La Última Tentación de Cristo" (Olmedo Bustos y otros) vs. Chile (2001), párr. 64; Caso Ivcher Bronstein vs. Perú (2001), párr. 146; Caso Herrera Ulloa vs. Costa Rica (2004), párr. 101.1 a) [argumentos de la Comisión Interamericana] y párr. 108; Caso Kimel vs. Argentina (2008), párr. 53; Caso Fontevecchia y D'Amico vs. Argentina (2011), párr. 42; Caso Mémoli vs. Argentina. (2013), párr. 119; Caso Vélez Restrepo y familiares vs. Colombia (2012), párr. 137; y Caso Norín Catrimán y otros (dirigentes, miembros y activista del pueblo indigena mapuche) vs. Chile (2014), párr. 371.

"Caso "La Última Tentación de Cristo" (Olmedo Bustos y otros) vs. Chile (2001), párr. 64; Caso Ivcher Bronstein vs. Perú (2001), párr. 147; Caso Herrera Ulloa vs. Costa Rica (2004), párr. 109; Caso Vélez Restrepo y familiares
} 
poder difundir las ideas por cualquier medio apropiado y hacerlas llegar al mayor número de destinatarios ${ }^{7}$. En cuanto a su dimensión social, ella se manifiesta en el derecho a recibir información de terceros ${ }^{8}$, así como el derecho a comunicar y de intercambiar ideas e informaciones con otros ${ }^{9}$. De ahí que los derechos de expresión y difusión, al ser considerados de igual importancia, sean indivisibles ${ }^{10}$. Todo lo anterior se fundamenta en que la libertad de expresión es considerada una piedra angular de cualquier sociedad democrática ${ }^{11}$.

Todo lo dicho explica que se prohíba la censura previa ${ }^{12}$, si bien la Corte estima que la libertad de expresión no es un derecho absoluto ${ }^{13}$. De ahí que quepan responsabilidades

vs. Colombia (2012), párr. 137 y 138; Caso Mémoli vs. Argentina (2013), párr. 119; y Caso Norín Catrimán y otros (dirigentes, miembros y activista del pueblo indígena mapuche) vs. Chile (2014), párr. 371-372.

7 Caso "La Última Tentación de Cristo" (Olmedo Bustos y otros) vs. Chile (2001), párr. 65; Caso Herrera Ulloa vs. Costa Rica (2004), párr. 109; Caso Vélez Restrepo y familiares vs. Colombia (2012), párr. 137-138; Caso Ivcher Bronstein vs. Perú (2001), párr. 147; y Caso Norín Catrimán y otros (dirigentes, miembros y activista del pueblo indígena mapuche) vs. Chile (2014), párr. 371-372.

8 Caso "La Última Tentación de Cristo" (Olmedo Bustos y otros) vs. Chile (2001), párr. 64; Caso Ivcher Bronstein vs. Perú (2001), párr. 148; Caso Herrera Ulloa vs. Costa Rica (2004), párr. 110; Caso Mémoli vs. Argentina (2013), párr. 119; Caso Vélez Restrepo y familiares vs. Colombia (2012), párr. 137; y Caso Norín Catrimán y otros (dirigentes, miembros y activista del pueblo indígena mapuche) vs. Chile (2014), párr. 371. También se alude a esto en la OC 5-/85, párr. 30-33.

9 Caso "La Última Tentación de Cristo" (Olmedo Bustos y otros) vs. Chile (2001), párr. 66; Caso Ivcher Bronstein vs. Perú (2001), párr. 146 y 148; Caso Herrera Ulloa vs. Costa Rica (2004), párr. 108 y 110; Caso Norín Catrimán y otros (dirigentes, miembros y activista del pueblo indígena mapuche) vs. Chile (2014), párr. 371; y Caso Vélez Restrepo y familiares vs. Colombia (2012), párr. 137 y 138. Como señala este último fallo: "Es por ello que a la luz de ambas dimensiones, la libertad de expresión requiere, por un lado, que nadie sea arbitrariamente menoscabado o impedido de manifestar su propio pensamiento y representa, por tanto, un derecho de cada individuo; pero implica también, por otro lado, un derecho colectivo a recibir cualquier información y a conocer la expresión del pensamiento ajeno" (párr. 138).

10 Caso "La Última Tentación de Cristo" (Olmedo Bustos y otros) vs. Chile (2001), párr. 65 y 67; Caso Ivcher Bronstein vs. Perú (2001), párr. 149; Caso Herrera Ulloa vs. Costa Rica (2004), párr. 101.1 a) [opinión de la Comisión Interamericana], 109 y 111; Caso Palamara Iribarne vs. Chile (2005), párr. 72 (que señala que "la expresión y la difusión del pensamiento son indivisibles"); Caso Vélez Restrepo y familiares vs. Colombia (2012), párr. 137; Caso Ricardo Canese vs. Paraguay (2004), párr. 78; y Caso Norín Catrimán y otros (dirigentes, miembros y activista del pueblo indígena mapuche) vs. Chile (2014), párr. 371. También se habla de esto en la OC-5/85, párr. 30, 33 y 36.

11 Esta es una idea constante en la jurisprudencia de la Corte: Caso "La Última Tentación de Cristo" (Olmedo Bustos y otros) vs. Chile (2001), párr. 64-68; Caso Ivcher Bronstein vs. Perú (2001), párr. 143 e) [opinión de la Comisión Interamericana], 149 y 152; Caso Herrera Ulloa vs. Costa Rica (2004), párr. 101.2 h) [opinión de la Comisión Interamericana] y párr. 112, 113, 115, 116 y 124; Caso Palamara Iribarne vs. Chile (2005), párr. 68 y 83; Caso Kimel vs. Argentina (2008), párr. 57 y 88; Caso Usón Ramírez vs. Venezuela (2009), párr. 47; Caso Fontevecchia y D’Amico vs. Argentina (2011), párr. 44 y 59-61; Caso Vélez Restrepo y familiares vs. Colombia (2012), párr. 139 y 141; y Caso Perozo y otros vs. Venezuela (2009), párr. 116. Esto además es tratado en la OC/85, párr. 54 y 70 y en el artículo 4 de la Carta Democrática Interamericana.

12 El principio se estableció en el Caso "La Última Tentación de Cristo" (Olmedo Bustos y otros) vs. Chile (2001), párr. 70: "Es importante mencionar que el artículo 13.4 de la Convención establece una excepción a la censura previa, ya que la permite en el caso de los espectáculos públicos pero únicamente con el fin de regular el acceso a ellos, para la protección moral de la infancia y la adolescencia. En todos los demás casos, cualquier medida preventiva implica el menoscabo a la libertad de pensamiento y de expresión". También puede verse Caso Palamara Iribarne vs. Chile (2005), párr. 68; Caso Uzcátegui y otros vs. Venezuela (2012), párr. 190; Caso Usón Ramírez vs. Venezuela (2009), párr. 48; Caso Vélez Restrepo y familiares vs. Colombia (2012), párr. 189; Caso Vélez Loor vs. Panamá (2010), párr. 207; Caso Kimel vs. Argentina (2008), párr. 54; Caso Fontevecchia y D’Amico vs. Argentina (2011), párr. 43; y Caso Norín Catrimán y otros (dirigentes, miembros y activista del pueblo indigena mapuche) vs. Chile (2014), párr. 377.

13 Caso "La Última Tentación de Cristo" (Olmedo Bustos y otros) vs. Chile (2001), párr. 61 d) [opinión de la Comisión Interamericana] y 70; Caso Kimel vs. Argentina (2008), párr. 54; Caso Fontevecchia y D’Amico vs. Argenti- 
ulteriores por un uso abusivo de este derecho, siempre que dichas responsabilidades no sean una censura previa encubierta o indirecta ${ }^{14}$. Con todo, la Corte considera que estas responsabilidades debieran tener un carácter más o menos restrictivo ${ }^{15}$, a fin que se apliquen en lo estrictamente necesario para limitar lo menos posible la libertad de expresión ${ }^{16}$. Por igual motivo, la restricción debe ser proporcional al derecho que se pretende proteger, siempre que esto último se fundamente en objetivos colectivos ${ }^{17}$.

Iguales argumentos explican que en general, la Corte sea bastante crítica en relación a las posibles responsabilidades penales posteriores fruto de un mal uso de la libertad de

na (2011), párr. 43; y Caso Mémoli vs. Argentina (2013), párr. 123. Esta situación está regulada en los arts. 13 y 29 de la Convención Americana de Derechos Humanos.

14 Caso Fontevecchia y D’Amico vs. Argentina (2011), párr. 43 y 53; Caso Kimel vs. Argentina (2008), párr. 54; Caso Palamara Iribarne vs. Chile (2005), párr. 71 y 79; Caso Ricardo Canese vs. Paraguay (2004), párr. 95; Caso Usón Ramírez vs. Venezuela (2009), párr. 47-48 y 63; Caso Herrera Ulloa vs. Costa Rica (2004), párr. 108-111 y 120; Caso "La Última Tentación de Cristo" (Olmedo Bustos y otros) vs. Chile (2001), párr. 70; y Caso Mémoli vs. Argentina (2013), párr. 123-125, 130-131 y 142-143; de manera más indirecta, en párr. 121-122. Como señala en su párr. 131: "En lo concerniente, el artículo 13.2 de la Convención Americana establece que las responsabilidades ulteriores por el ejercicio de la libertad de expresión, deben cumplir con los siguientes requisitos de forma concurrente: (i) estar previamente fijadas por ley, en sentido formal y material; (ii) responder a un objetivo permitido por la Convención Americana ('el respeto a los derechos o a la reputación de los demás' o la protección de la seguridad nacional, el orden público o la salud o la moral públicas'), y (iii) ser necesaria en una sociedad democrática (para lo cual deben cumplir con los requisitos de idoneidad, necesidad y proporcionalidad)". O como se señala en el Caso Tristán Donoso vs. Panamá (2009), se exigen "requisitos de idoneidad, necesidad y proporcionalidad" (párr. 56). Ideas similares en Caso Herrera Ulloa vs. Costa Rica (2004), párr. 120-121 y 123. Véase además, la OC-5/85, párr. 36-39. De manera indirecta, también en Caso Manuel Cepeda Vargas vs. Colombia (2010), párr. 206 y 226.

${ }_{15}$ Es por eso que "Las restricciones a la libertad de expresión deben estar orientadas a satisfacer un interés público imperativo. Entre varias opciones debe escogerse aquella que restrinja en menor escala el derecho protegido, y la restricción debe ser proporcionada al interés que la justifica" (Caso Herrera Ulloa vs. Costa Rica (2004), párr. 101.1 b) [opinión de la Comisión Interamericana]). En consecuencia, "El Tribunal ha sostenido que cuando por medio del poder público se establecen medios o efectúan acciones para impedir la libre circulación de información, ideas, opiniones o noticias se produce una violación radical tanto del derecho de cada persona a expresarse como del derecho de todos a estar bien informados, de modo que se afecta una de las condiciones básicas de una sociedad democrática' [alude al Caso Palamara Iribarne vs. Chile (2005) párr. 68 y a la OC-5/85, párr. 54]. En tal hipótesis se encuentran 'la censura previa, el secuestro o la probibición de publicaciones y, en general, todos aquellos procedimientos que condicionan la expresión o la difusión de información al control del Estado' [alude a los mismos documentos ya señalados]" (Caso Vélez Restrepo y familiares vs. Colombia (2012) párr. 139).

16 Caso Palamara Iribarne vs. Chile (2005), párr. 68 y 83; Caso Ivcher Bronstein vs. Perú (2001), párr. 152; Caso Usón Ramírez vs. Venezuela (2009), párr. 47-48; Caso Perozo y otros vs. Venezuela (2009), párr. 117; Caso Kimel vs. Argentina (2008), párr. 54 y 56; Caso Apitz Barbera y otros ("Corte Primera de lo Contencioso Administrativo") vs. Venezuela (2008), párr. 131; Caso Tristán Donoso vs. Panamá (2009), párr. 110; Caso Ricardo Canese vs. Paraguay (2004), párr. 96; y Caso Herrera Ulloa vs. Costa Rica (2004), párr. 120, 121 y 123. Como señala este último fallo: "Dado este estándar, no es suficiente que se demuestre, por ejemplo, que la ley cumple un propósito útil u oportuno; para que sean compatibles con la Convención las restricciones deben justificarse según objetivos colectivos que, por su importancia, preponderen claramente sobre la necesidad social del pleno goce del derecho que el artículo 13 garantiza y no limiten más de lo estrictamente necesario el derecho proclamado en dicho artículo. Es decir, la restricción debe ser proporcionada al interés que la justifica y ajustarse estrechamente al logro de ese legitimo objetivo" (párr. 121). Puede verse también la OC-5/85, párr. 36, 46 y 54.

17 Caso Palamara Iribarne vs. Chile (2005), párr. 79 y 85; Caso Kimel vs. Argentina (2008), párr. 83; Caso Herrera Ulloa vs. Costa Rica (2004), párr. 121 y 123; Caso Claude Reyes y otros vs. Chile, párr. 91; y Caso Chaparro Álvarez y Lapo Íñiguez vs. Ecuador (2007), párr. 93. Véase la OC-5/85, párr. 46. 
expresión $^{18}$, lo que tenderá a cambiar en el último tiempo -al menos en algunos casos-, según se verá en seguida. Algo similar ocurre con las sanciones civiles y otras accesorias, que no pueden ser desproporcionadas ${ }^{19}$. Además, estima que las restricciones a este derecho deben analizarse en su contexto, no como actos aislados ${ }^{20}$, razón por la cual debe existir un juicio de ponderación respecto de los derechos en pugna ${ }^{21}$. De ahí por ejemplo, que exista una relación entre libertad de expresión y derecho de asociación ${ }^{22}$.

Ahora bien, a pesar de su defensa de este derecho, la Corte igualmente señala que también es muy importante la protección de la vida privada ${ }^{23}$, existiendo además, una delicada relación con el derecho a la honra y el derecho al honor ${ }^{24}$, incluso para las personas ju-

18 Caso Herrera Ulloa vs. Costa Rica (2004), párr. 121-123 y 132-135; Caso Palamara Iribarne vs. Chile (2005), párr. 64 c) [opinión de la Comisión Interamericana], 85 (nota 47) y 88; Caso Kimel vs. Argentina (2008), párr. 78, 83 (nota 41) y 85; Caso Uzcátegui y otros vs. Venezuela (2012), párr. 170; Caso Mémoli vs. Argentina (2013), párr. 114; Caso Ricardo Canese (2004), párr. 104; Caso Norín Catrimán y otros (dirigentes, miembros y activista del pueblo indígena mapuche) vs. Chile (2014), párr. 376; y Caso Usón Ramírez vs. Venezuela (2009), párr. 67 y 69-88.

19 Caso Fontevecchia y D'Amico vs. Argentina (2011), párr. 72 y 74; y Caso Norín Catrimán y otros (dirigentes, miembros y activista del pueblo indigena mapuche) vs. Chile (2014), párr. 373-376 y 421.

20 Caso Ivcher Bronstein vs. Perú (2001), párr. 154 y 162; y Caso Palamara Iribarne vs. Chile (2005), párr. 94.

21 Esta exigencia de un juicio de ponderación en relación con la libertad de expresión, ha sido desarrollada desde hace pocos años: Caso Kimel vs. Argentina (2008), párr. 51 y 84; Caso Usón Ramírez vs. Venezuela (2009) párr. 80; Caso Tristán Donoso vs. Panamá (2009), párr. 123; Caso Fontevecchia y D’Amico vs. Argentina (2011), párr. 66 y 71; y Caso Mémoli vs. Argentina (2013), párr. 127, 140 y 143. Con todo, se alude de manera más temprana a esto en el Caso Ricardo Canese vs. Paraguay (2004) párr. 105.

22 Caso Gudiel Álvarez y otros ("Diario Militar") vs. Guatemala (2012), párr. 319, donde se señala que si se vulnera la libertad de asociación, puede afectarse también la libertad de expresión, aun cuando no sea el caso de la presente sentencia.

23 Caso Fontevecchia y D’Amico vs. Argentina (2011), párr. 17 [opinión de la Comisión Interamericana], la cual señala que la protección a la vida privada es "una de las más importantes conquistas de los regímenes democráticos". Con todo, estas protecciones deben establecerse por vía legal y de forma restrictiva (ibid, párr. 89-90).

24 Si bien en un comienzo se señala que el derecho a la libertad de expresión primaría sobre otros, razón por la cual no puede en principio ser restringido (como por ejemplo en el Caso "La Última Tentación de Cristo" (Olmedo Bustos y otros) vs. Chile (2001), passim, especialmente párr. 63-73, 79-80, 88 y 97, además de los alegatos de la Comisión Interamericana y varios peritajes reproducidos en la sentencia), de manera más reciente, si bien al aludir al derecho a la honra o al derecho al honor, la Corte ha apuntado a la necesidad de armonizar estos derechos con la libertad de expresión. Lo dice de manera particularmente clara en el Caso Mémoli vs. Argentina (2013), párr. 127: "Tanto la libertad de expresión como el derecho a la honra, derechos ambos protegidos por la Convención, revisten suma importancia, por lo cual es necesario garantizar ambos derechos, de forma que coexistan de manera armoniosa. El ejercicio de cada derecho fundamental tiene que hacerse con respeto y salvaguarda de los demás derechos fundamentales. En ese proceso de armonización le cabe un papel medular al Estado buscando establecer las responsabilidades y sanciones que fueren necesarias para obtener tal propósito. La necesidad de proteger los derechos que pudieran verse afectados por un ejercicio abusivo de la libertad de expresión, requiere la debida observancia de los limites fijados a este respecto por la propia Convención. La solución del conflicto que se presenta entre ambos derechos requiere de una ponderación entre los mismos, a través de un juicio de proporcionalidad, para lo cual deberá examinarse cada caso, conforme a sus caracteristicas y circunstancias, a fin de apreciar la existencia e intensidad de los elementos en que se sustenta dicho juicio”. Ideas complementarias en ibid, párr. 123, 125-127, 139 y 142-143; y de forma más o menos completa en relación al párrafo transcrito, en Caso Kimel vs. Argentina (2008), párr. 51, 56, 75, 77 y 84; Caso Fontevecchia y D'Amico vs. Argentina (2011), párr. 50 y 59; Caso Usón Ramírez vs. Venezuela (2009), párr. 63; y Caso Palamara Iribarne vs. Chile (2005), párr. 79; Caso Tristán Donoso vs. Panamá (2009), párr. 93. 
rídicas $^{25}$. Con todo, ello no significa que fruto de la libertad de expresión no exista la posibilidad de ofender a terceros, pues en caso que esto último se prohibiera, el debate se haría prácticamente imposible ${ }^{26}$. Empero, quien se sienta vulnerado en sus derechos tiene toda la libertad para recurrir a las instancias judiciales si lo estima necesario ${ }^{27}$. En consecuencia, este tribunal aspira a que exista un equilibrio entre libertad de expresión y vida privada ${ }^{28}$, dejando en claro, no obstante, que en el caso de los funcionarios públicos, esta protección es menor, en razón del necesario debate que debe existir en las sociedades democráticas ${ }^{29}$.

Sin embargo, y según se ha adelantado, en el último tiempo pareciera apreciarse una evolución en cuanto a las responsabilidades posteriores que pudiera originar un abuso de la libertad de expresión. En efecto, en fallos recientes (sobre todo a partir de 2008), defiende en un tono más benévolo la posibilidad de aplicar sanciones civiles y también penales ${ }^{30}$.

${ }^{25}$ Caso Usón Ramírez vs. Venezuela (2009), párr. 64-65. Con todo, esta posibilidad fue desechada en esta sentencia.

${ }^{26}$ Caso Kimel vs. Argentina (2008), párr. 88: "En la arena del debate sobre temas de alto interés público, no solo se protege la emisión de expresiones inofensivas o bien recibidas por la opinión pública, sino también la de aquellas que chocan, irritan o inquietan a los funcionarios públicos o a un sector cualquiera de la población. En una sociedad democrática, la prensa debe informar ampliamente sobre cuestiones de interés público, que afectan bienes sociales, y los funcionarios rendir cuentas de su actuación en el ejercicio de sus tareas públicas". Ideas similares en Caso La Última Tentación de Cristo (Olmedo Bustos y otros) vs. Chile (2001), párr. 69; Caso Ivcher Bronstein vs. Perú (2001), párr. 152, y Caso Ricardo Canese vs. Paraguay (2004), párr. 83. Por otro lado, no deja de ser interesante la opinión del perito Julio César Rivera (h.), vertida en el Caso Fontevecchia y D'Amico vs. Argentina (2011): "La consideración como violación a la intimidad de toda mortificación de los sentimientos de otro es claramente incompatible con un principio fundamental de la libertad de expresión según el cual el Estado no puede probibir o castigar una determinada idea u opinión porque resulta ofensiva para ciertas personas" (párr. 88, nota 64).

27 Caso Valle Jaramillo y otros vs. Colombia (2008), párr. 196; Caso Kimel vs. Argentina (2008), párr. 55; Caso Tristán Donoso vs. Panamá (2009), párr. 111, 112 y 118; y Caso Usón Ramírez vs. Venezuela (2009), párr. 46.

28 Caso Fontevecchia y D'Amico vs. Argentina (2011), párr. 50: "la Corte debe encontrar un equilibrio entre la vida privada y la libertad de expresión que, sin ser absolutos, son dos derechos fundamentales garantizados en la Convención Americana y de la mayor importancia en una sociedad democrática. El Tribunal recuerda que el ejercicio de cada derecho fundamental tiene que hacerse con respeto y salvaguarda de los demás derechos fundamentales. En ese proceso de armonización le cabe un papel medular al Estado buscando establecer las responsabilidades y sanciones que fueren necesarias para obtener tal propósito. La necesidad de proteger los derechos que pudieran verse afectados por un ejercicio abusivo de la libertad de expresión, requiere la debida observancia de los límites fjados a este respecto por la propia Convención". Ideas similares en Caso Kimel vs. Argentina (2008), párr. 56.

${ }_{29}$ Caso Fontevecchia y D’Amico vs. Argentina (2011), párr. 59-61; Caso Kimel vs. Argentina (2008), párr. 86-88; Caso Tristán Donoso vs. Panamá (2009), párr. 93, 115 y 122; y Caso Herrera Ulloa vs. Costa Rica (2004), párr. 125-129.

30 Caso Mémoli vs. Argentina (2013), párr. 126: "La Corte reitera su jurisprudencia constante en el sentido que 'no estima contraria a la Convención cualquier medida penal a propósito de la expresión de informaciones u opiniones' [alude a Caso Kimel vs. Argentina (2008), párr. 78, y Caso Fontevecchia y D’Amico vs. Argentina (2011), párr. 55]. Tanto la vía civil como la vía penal son legitimas, bajo ciertas circunstancias y en la medida que reúnan los requisitos de necesidad y proporcionalidad, como medios para establecer responsabilidades ulteriores ante la expresión de informaciones u opiniones que afecten la honra o la reputación. [...] Asimismo, este Tribunal ha establecido que el instrumento penal puede ser idóneo para salvaguardar el bien jurídico que se quiere proteger, en la medida en que podría estar en capacidad de contribuir a la realización de dicho objetivo". Ideas similares en ibid, párr. 133, 137139, 144, 148-149, 204 y 217; Caso Fontevecchia y D’Amico vs. Argentina (2011), párr. 49, 53 y 55; Caso Kimel vs. Argentina (2008), párr. 71, 75 y 76-78; Caso Usón Ramírez vs. Venezuela (2009), párr. 64 y 74; Caso Tristán Donoso vs. Panamá (2009), párr. 118.

Es de advertir que en el Caso Mémoli, a diferencia del Caso Kimel, la Corte Interamericana sí consideró correcta la sanción penal impuesta a los demandantes por las expresiones vertidas que dieron origen a esa demanda. 
En todo caso, y sin perjuicio de dar la impresión que la Corte ha ido evolucionando respecto de la posibilidad de establecer sanciones penales, llama profundamente la atención que ella hable de su "jurisprudencia constante" en este sentido, y solo aluda a dos fallos (Kimel y Fontevecchia), lo que creemos, corrobora que se trata de un proceso jurisprudencial reciente ${ }^{31}$.

Lo anterior podría dar origen, a nuestro juicio, a un problema que ella trata de evitar: que el mismo orden jurídico pueda terminar transformándose en un poderoso factor intimidatorio para la libertad de expresión ${ }^{32}$. Sobre esto se volverá al final de este trabajo.

\section{LA CONVENCIÓN INTERAMERICANA CONTRA TODA FORMA DE DISCRIMINACIÓN E INTOLERANCIA}

La Convención Interamericana contra Toda Forma de Discriminación e Intolerancia fue aprobada por la Asamblea General de la OEA el 6 de junio de 2013, junto a otra de nombre similar: la Convención Interamericana contra el Racismo, la Discriminación Racial, y Formas Conexas de Intolerancia (que no se analiza aquíi ${ }^{33}$ ). Ninguna es aún vinculante,

31 Lo anterior se refuerza más todavía, si se tiene en cuenta que en el Caso Mémoli vs. Argentina (2013), nota 239 (párr. 126), alude a diferentes documentos de la ONU (y por tanto, ajenos al sistema interamericano): "Informe del relator especial sobre la promoción y protección del derecho a la libertad de opinión y expresión, Sr. Frank La Rue, A/HRC/14/23, 4 de junio de 2012, párr. 80; Informe del Relator Especial sobre la promoción y protección del derecho a la libertad de opinión y expresión. Sr. Ambeyi Ligabo, 'promoción y protección de todos los derechos humanos, civiles, políticos, económicos, sociales y culturales, incluido el derecho al desarrollo', A/HRC/7/14, 28 de febrero de 2008, párr. 39, e Informe del Relator Especial sobre la promoción y protección del derecho a la libertad de opinión y expresión, Sr. Ambeyi Ligabo, implementación de la Resolución de la Asamblea General 60/251 de 15 de marzo de 2006 titulada 'Consejo de Derechos Humanos”, A/HRC/7/14, 2 de enero de 2007, párr. 46”'.

Por su parte, en el Caso Usón Ramírez vs. Venezuela (2009), en su nota 59 (párr. 74), alude solo a un caso interamericano (el Caso Kimel, párr. 78) y sobre todo a jurisprudencia europea: "Mamère v. France, no. 12697/03, $\$$ 27, ECHR 2006; ECHR, Castells v. Spain. judgment of 23 of April 1992, \42, \46. Series A no. 236, y Cumpana and Mazare v. Romania [GC], no. 33348/96, \$ 115, ECHR 2004-XI”. Por otro lado, en el Caso Mémoli vs. Argentina (2013), nota 240 (párr. 126), dentro del mismo párrafo en que alude a la posibilidad de sanciones penales, menciona el Caso Herrera Ulloa, párr. 120. Sin embargo, esta última cita solo habla, y de manera bastante más vaga, de posibles sanciones posteriores por abusos de la libertad de expresión, sin mencionar las de tipo penal. Todo esto refuerza, a nuestro juicio, que se trataría de una evolución jurisprudencial reciente.

32 Caso Uzcátegui y otros vs. Venezuela (2012), párr. 190: "la Corte ha establecido que es posible que la libertad de expresión se vea ilegítimamente restringida por condiciones de facto que coloquen, directa o indirectamente, en situación de riesgo o mayor vulnerabilidad a quienes la ejercen. Es por ello que el Estado debe abstenerse de actuar de manera tal que propicie, estimule, favorezca o profundice esa vulnerabilidad y ha de adoptar, cuando sea pertinente, medidas necesarias y razonables para prevenir violaciones o proteger los derechos de quienes se encuentren en tal situación". Ideas similares en Caso Manuel Cepeda Vargas vs. Colombia (2010), párr. 172; Caso Perozo y otros vs. Venezuela (2009), párr. 118; Caso Vélez Restrepo y familiares vs. Colombia (2012), párr. 189; Caso Vélez Loor vs. Panamá (2010), párr. 207; y Caso Norín Catrimán y otros (dirigentes, miembros y activista del pueblo indígena mapuche) vs. Chile (2014), párr. 376. De forma más indirecta, en Caso Tristán Donoso vs. Panamá (2009), párr. 129, y Caso Fontevecchia y D`Amico vs. Argentina (2011), párr. 74.

33 En efecto, salvo las alusiones que se hacen a la Convención Internacional sobre la Eliminación de Todas las Formas de Discriminación Racial, de 1965, algunas consideraciones de su Preámbulo (párr. 5 y 14) y su art. 1.4, su articulado y disposiciones son prácticamente idénticos a las de la convención que se comenta en este trabajo, al punto que podría considerársela una especificación de la anterior, referida así a la discriminación o la intolerancia por motivos de raza, color, linaje, origen nacional o étnico, todo lo cual se aplica, entre otros, a los pueblos indígenas y a los afrodescendientes. Debe dejarse constancia que dentro del Preámbulo, el párr. 5 
en atención a no haberse depositado hasta la fecha de término de este trabajo, el segundo instrumento de ratificación o de adhesión que se exige para tal efecto. En atención a la importancia que tienen sus disposiciones de cara a la libertad de expresión, se hará un análisis crítico de la misma. Con todo, debe advertirse desde ya, que puede apreciarse sin mayor dificultad un notable cambio de perspectiva en relación a los documentos que protegen la libertad de expresión analizados en el epígrafe 1 de este trabajo, pues se llama a la autoridad a tener un papel protagónico en el combate contra la discriminación y la intolerancia. También es posible constatar que en este instrumento están plasmados los deberes de los Estados de prevenir ${ }^{34}$, investigar ${ }^{35}$, sancionar ${ }^{36}$ y reparar $^{37}$ posibles violaciones de los derechos humanos, siendo como intentará mostrarse, aspectos sin los cuales resulta imposible comprender esta convención.

\subsection{JUSTIFICACIÓN Y CONCEPTOS FUNDAMENTALES}

En su Preámbulo, luego de expresar su deseo de erradicar toda forma de discriminación e intolerancia (párr. 2) y de fomentar y estimular el respeto por los derechos de todas las personas y grupos (párr. 3), declara que los principios de la igualdad y de la no discriminación entre los seres humanos son "conceptos democráticos dinámicos", de los cuales surge la obligación del Estado de adoptar medidas que sean necesarias para su plena vigencia "en todas sus manifestaciones individuales, estructurales e institucionales", tanto en el ámbito público como privado (párr. 4). Por eso deben crearse las condiciones para que las personas puedan expresar, preservar y desarrollar su identidad (párr. 9), a fin de proteger el plan de vida de individuos y comunidades en riesgo de ser segregados y marginados (párr. 10), sobre todo por el aumento de los delitos de odio (párr. 11), razón por la cual se destaca el papel fundamental de la educación para alcanzar estos objetivos (párr. 12).

Luego, en su artículo 1.1, define "lo que entiende por Discriminación: "es cualquier distinción, exclusión, restricción o preferencia, en cualquier ámbito público o privado, que tenga el objetivo o el efecto de anular o limitar el reconocimiento, goce o ejercicio, en condiciones de igualdad, de uno o más derechos humanos o libertades fundamentales consagrados en los instrumentos internacionales aplicables a los Estados Partes". Y en su

\footnotetext{
denuncia que el racismo "exhibe una capacidad dinámica de renovación que le permite asumir nuevas formas de difusión y expresión política, social, cultural y lingüistica"; y el párr. 14 hace referencia a la convención de 1965 aludida al principio de esta nota, señalando la importancia de suscribir el instrumento regional que prologa. Por su parte, el art. 1.4 condena las teorías racistas en atención a ser el origen de un cúmulo de discriminaciones. En todo lo demás, según se ha dicho (definiciones, deberes del Estado y mecanismos de protección y seguimiento) las dos convenciones son prácticamente idénticas, razón por la cual todo lo que se diga respecto del documento que aquí se analiza se entiende aplicable a ambas.

34 Este tema se desarrolla en el punto 3.4 de este apartado.

35 Sobre el deber de investigar puede consultarse Castilla (2011) pp. 156-157; Nogueira (2012b) pp. 76-79; Nogueira (2012a) p. 155.

36 Sobre el deber de sancionar hablan CanÇAdo (2006) pp. 243-244; Ferrer Mac-Gregor (2011) pp. 394397; Castilla (2011) pp. 156-157.

37 Sobre el deber de reparar puede consultarse: Gómez Robledo (2009) pp. 143-146; Aguilar (2009) pp. 131-132; Castilla (2011) pp. 156-157; Galdámez (2007) pp. 440 y 453-454; Ferrer Mac-Gregor y Pelayo (2012) pp. 154 y 161-162; MeIER (2011) p. 369.
} 
inciso segundo, señala sus causas: "La discriminación puede estar basada en motivos de nacionalidad, edad, sexo, orientación sexual, identidad y expresión de género, idioma, religión, identidad cultural, opiniones políticas o de cualquier otra naturaleza, origen social, posición socioeconómica, nivel de educación, condición migratoria, de refugiado, repatriado, apátrida o desplazado interno, discapacidad, característica genética, condición de salud mental o física, incluyendo infectocontagiosa, psíquica incapacitante o cualquier otra”.

Ahora bien, un primer problema que salta a la vista es el amplísimo concepto de discriminación establecido. En efecto, si la acción ilícita puede ser "cualquier distinción, exclusión, restricción o preferencia”, ella resulta tremendamente vaga e imprecisa. En segundo lugar, la acción discriminatoria puede haber sido realizada con ese propósito ("que tenga por objetivo") o haberse producido este efecto sin él ("que tenga... el efecto"). Luego, en tercer lugar, si el objetivo o efecto de dichas acciones puede ser "anular o limitar el reconocimiento, goce o ejercicio, en condiciones de igualdad, de uno o más derechos humanos o libertades fundamentales consagrados en los instrumentos internacionales aplicables a los Estados Partes", tanto sus eventuales efectos ("anular o limitar"), el modo como podría afectar al derecho supuestamente conculcado ("reconocimiento, goce o ejercicio") y finalmente, cuáles derechos podrían ser pasados a llevar (al remitirse a cualquier instrumento internacional de derechos humanos), también se tornan impredecibles. Ello, en cuarto lugar, sin perjuicio de las 25 causales que se contemplan en su inciso segundo, que a fuer de su notable amplitud, no son taxativas sino meramente ejemplares, pues la disposición posee un final residual abierto ("o cualquier otra”). Finalmente, y en quinto lugar, su ámbito de aplicación es completamente universal, al poder darse en cualquier ámbito público o privado, todo lo cual obligaría al Estado a tomar medidas en todas las manifestaciones individuales, estructurales e institucionales de la vida, si se recuerda el Preámbulo (párr. 4). En suma, prácticamente cualquier comportamiento podría ser considerado discriminatorio.

Posteriormente esta convención distingue entre la Discriminación indirecta, esto es, "la que se produce, en la esfera pública o privada, cuando una disposición, un criterio o una práctica, aparentemente neutro es susceptible de implicar una desventaja” para personas o grupos, salvo que ello esté justificado por el derecho internacional de los derechos humanos (art. 1.2); y la Discriminación múltiple o agravada (art. 1.3), esto es, la que involucra a dos o más de los criterios señalados en el art. 1.1. Con todo, no serán consideradas discriminatorias las medidas especiales a favor de personas o grupos vulnerables (art. 1.4).

De esta forma -y nuevamente tanto en el ámbito público como privado-, la discriminación indirecta podría aplicarse a toda clase de prescripción o de noma, sea jurídica o no (puesto que habla de "disposición"), a cualquier forma de apreciar las cosas, por muy subjetiva que sea ("un criterio"), o a cualquier modo de actuar ("una práctica"), con todo lo ambiguo que esto pueda resultar. Pero además, al tratarse de situaciones aparentemente neutras, habría por añadidura que descubrir su discriminación oculta. Sin perjuicio de lo anterior, no se exige que dicha disposición, criterio o práctica haya producido necesariamente un daño, sino simplemente que pueda causar una discriminación de forma potencial, con lo cual se llama a la autoridad a prever posibles ilícitos (vinculados al deber de prevenir), aunque no se hayan producido efectivamente. Todo lo dicho sin contar, finalmente, con la amplísima interpretación que puede dársele al término "desventaja”. Es decir, nueva- 
mente se arriba a una situación de posibles actos ilícitos tremendamente indeterminada, sin perjuicio de poder darse casos de discriminación múltiple o agravada si se dan conjuntamente dos o más de los criterios señalados en el art. 1.1.

Por último, se define intolerancia señalando que "es el acto o conjunto de actos o manifestaciones que expresan el irrespeto, rechazo o desprecio de la dignidad, características, convicciones u opiniones de los seres humanos por ser diferentes o contrarias. Puede manifestarse como marginación y exclusión de la participación en cualquier ámbito de la vida pública o privada de grupos en condiciones de vulnerabilidad o como violencia contra ellos" (art. 1.5).

Con semejante redacción, nuevamente se arriba al mismo problema de imprecisión, pues no solo se refiere a "actos", sino al amplio concepto de "manifestaciones", con todas las sutilezas que ambos términos pueden tener. Ello sin olvidar que sus modos de expresión (“irrespeto, rechazo o desprecio") son amplísimos y difíciles de determinar, sin perjuicio de poder quedar entregados peligrosamente al criterio subjetivo del supuesto ofendido, abriendo así la puerta para abusos de su parte. Además, estos modos de expresión aluden al rechazo de casi cualquier aspecto o elemento de la supuesta víctima ("dignidad, características, convicciones u opiniones”), en razón de prácticamente cualquier motivo que pudiera tener el supuesto infractor, con manifestaciones nuevamente amplísimas, algunas de difícil comprobación, como "marginación” o "exclusión”, en cualquier aspecto de la vida pública o privada, esto es, nuevamente con un ámbito de aplicación universal.

Como si fuera poco, la convención señala que los principios de la igualdad y la no discriminación son "conceptos democráticos dinámicos" (Preámbulo, párr. 4), contando además con una norma de reenvío para incluir otros criterios de discriminación e intolerancia contenidos en instrumentos internacionales (Preámbulo, párrafo 6), o también en normas nacionales (art. 16), todo ello en virtud del principio pro homine.

En consecuencia, puede concluirse a la luz del tenor literal de estos preceptos, que prácticamente cualquier conducta puede ser considerada intolerante o discriminatoria, sin perjuicio de la eventual influencia en esta consideración de lo que sientan las supuestas víctimas.

Lo anterior se torna aún más impredecible, si se toman en cuenta algunas de las reglas de interpretación del Derecho Internacional de los Derechos Humanos que ha ido estableciendo la Corte. Pese a ser un tema que por su extensión no puede ser tratado aquí, debe recordarse que según este modo de proceder, los tratados no deben interpretarse tanto a la luz de su tenor literal, ni de las intenciones de sus redactores ${ }^{38}$, sino de acuerdo con las actuales circunstancias de nuestras sociedades: al ser "instrumentos vivos" ${ }^{39}$, dicha interpretación debe ser evolutiva, dinámica, progresista ${ }^{40}$ y finalista ${ }^{41}$. Además, los derechos humanos son indivisibles ${ }^{42}$ e interdependientes ${ }^{43}$, razón por la cual deben entenderse de forma

\footnotetext{
38 CANÇADO (2006) pp. 48-49.

39 VÁsquez y Serrano (2011) p. 145; Galdámez (2007) pp. 343-344.

40 Cançado (2006) pp. 46-49; Galdámez (2007) pp. 442-486; Vásquez y Serrano (2011) pp. 159-164.

41 Amaya (2005) pp. 344-345; Núñez Poblete (2011) p. 54; Cançado (2006) pp. 27, 40 y 168-169.

42 Vásquez y Serrano (2011) pp. 148-159; Orozco (2011) pp. 93-94; Albanese (s/f) p. 7; Fríes (2012) pp. 169-171; Amaya (2005) p. 345; CANÇADo (2006) pp. 65-72 y 93-144.

43 Vásquez y Serrano (2011) pp. 151-155; Orozco (2011) pp. 85-98 p. 93; Albanese (s/f) p. 7.
} 
sistemática ${ }^{44}$, lo que permite un reforzamiento mutuo. Por eso se habla de una interpretación holística a su respecto ${ }^{45}$.

Igualmente, los principios pro homine y de progresividad ${ }^{46}$, así como las normas de reenvío -que permiten acudir casi a cualquier norma o jurisprudencia nacional o internacional que aluda a estas temáticas-, hacen a nuestro juicio que esta convención pueda utilizarse para prohibir o sancionar prácticamente cualquier conducta. En suma, de no ser cuidadosos en su aplicación, podría llegar a convertirse en algo parecido a una ley penal en blanco.

\subsection{Deberes del Estado}

Pasando desde el ámbito conceptual al de la acción, esto es, a las medidas que la convención ordena tomar al Estado no solo para castigar actos de discriminación o intolerancia ya producidos, sino sobre todo para impedirlos (lo cual se vincula directamente con el deber de prevenir), nuevamente se percibe una notable amplitud de los mecanismos que se establecen y, como se ha mencionado, un notable cambio de perspectiva en relación a los instrumentos que protegen la libertad de expresión.

En efecto, la convención llama a la autoridad a tener un papel fundamental en la lucha contra la discriminación y la intolerancia, adoptando medidas previas generales en favor de los sujetos y grupos afectados (Preámbulo, párr. 4). Luego agrega: "Los Estados se comprometen a prevenir, eliminar, prohibir y sancionar, de acuerdo con sus normas constitucionales y con las disposiciones de esta Convención, todos los actos y manifestaciones de discriminación e intolerancia, incluyendo: i. El apoyo privado o público a actividades discriminatorias o que promuevan la intolerancia, incluido su financiamiento. ii. La publicación, circulación o diseminación, por cualquier forma y/o medio de comunicación, incluida la Internet, de cualquier material que: a) defienda, promueva o incite al odio, la discriminación y la intolerancia; b) apruebe, justifique o defienda actos que constituyan o hayan constituido genocidio o crímenes de lesa humanidad, según se definen en el derecho internacional, o promueva o incite a la realización de tales actos" (art. $4^{\circ}$ ).

Como puede apreciarse, lo anterior conlleva una notable e invasiva labor de vigilancia por parte de la autoridad, tanto previa ("prevenir" y "prohibir") como posterior ("eliminar" y "sancionar") de prácticamente cualquier actuación de los ciudadanos que pudiera producir discriminación o intolerancia, tanto en el ámbito público como privado, lo cual afectaría también a toda forma de comunicación de ideas, incluyendo Internet. No solo eso: además, de acuerdo a esta convención, la autoridad estaría legitimada para interferir respecto de acciones previas y hasta indirectas que pudieran producir estos ilícitos ("apoyo privado o público... incluido su financiamiento”). En suma, lo anterior exigiría una fiscalización constante y total de la autoridad de todo lo que ocurra en su país, pues como se ha dicho, además de los conceptos tan amplios establecidos, en el caso de la discriminación, no se exige que ella se haya efectivamente producido, sino solo que pueda generarse, incluso por acciones que no aparentan este fin y también si ello ha sido involuntario. En

\footnotetext{
44 Vásquez y Serrano (2011) pp. 151-155; Orozco (2011) pp. 85-98 p. 93; Fríes (2012) pp. 169-171.

45 Vásquez; Serrano (2011) p. 155; Cançado (2006) pp. 64 y 166-167.

46 Aguilar (2012) p. 729; Castilla (2011) p. 157.
} 
realidad, toda la normativa que se comentará a continuación gira en torno a la misma idea: una vigilancia casi enfermiza de la actuación de los ciudadanos, viendo discriminación e intolerancia en cualquier parte.

Luego, y a fin de evitar actos de discriminación o intolerancia, y haciendo un claro uso del principio pro homine, la convención establece que los Estados deben impedir "Cualquier restricción discriminatoria del goce de los derechos humanos consagrados en los instrumentos internacionales y regionales aplicables y en la jurisprudencia de las cortes internacionales y regionales de derechos humanos, en especial los aplicables a las minorías o grupos en condiciones de vulnerabilidad y sujetos a discriminación" (Art. 4 viii), a fin de impedir "La denegación del acceso a cualquiera de los derechos sociales, económicos y culturales, en función de alguno de los criterios enunciados en el artículo 1.1 de esta Convención” (art. 4 xii).

Sin embargo, con semejante normativa aplicable, y aunque ya se haya dicho, casi no habría conducta que de alguna u otra manera pudiera ser considerada discriminatoria o intolerante. $\mathrm{O}$ si se prefiere, ante un reenvío normativo tan generoso, es absolutamente imposible saber a ciencia cierta cuándo se estaría cometiendo un ilícito, pues el catálogo de derechos afectados es prácticamente inconmensurable. Lo anterior, sin perjuicio, como se ha dicho, de las dúctiles normas de interpretación de los derechos humanos desarrolladas por la Corte, así como al carácter dinámico y democrático de estos conceptos.

Ahora bien, contrariamente a lo que ocurre con los derechos eventualmente vulnerables o las conductas que podrían generar responsabilidad, la convención es bastante más explícita y clara en relación a los mecanismos de acción que debieran adoptar los Estados, aun cuando estos resulten también bastante amplios. Es por eso que llama a evitar "La elaboración y la utilización de contenidos, métodos o herramientas pedagógicos que reproduzcan estereotipos o preconceptos en función de alguno de los criterios enunciados en el artículo 1.1 de esta Convención" (art. 4 x). Como puede apreciarse, aun cuando sea un tema que no puede tratarse aquí, las restricciones que lo anterior puede traer para la libertad de enseñanza son manifiestas. La convención también alude a la educación en los párr. 12 y arts. 6 y 7.

Más adelante, los arts. 5, 6, 7 y 11 muestran claramente hasta qué punto se llama a intervenir a la autoridad, y vienen a reforzar lo señalado hasta ahora, pudiendo hacerse a su respecto observaciones análogas a las ya indicadas. El primero señala que los Estados deben “adoptar las políticas especiales y acciones afirmativas" en favor de las personas o grupos vulnerables, las que no serán consideradas discriminatorias (art. 5). En este mismo orden de ideas, deben formularse y aplicarse políticas educativas, laborales y legislativas en pro de la no discriminación y de la tolerancia (art. 6).

En estrecha relación con lo dicho, se ordena "adoptar la legislación que defina y prohíba claramente la discriminación y la intolerancia, aplicable a todas las autoridades públicas, así como a todas las personas naturales o físicas, y jurídicas, tanto en el sector público como privado" en un cúmulo de áreas (empleo, educación, vivienda, salud, etc.) "y a derogar o modificar toda legislación que constituya o dé lugar a discriminación e intolerancia” (art. 7), si fruto de lo anterior se les deniega el acceso a personas o grupos a cualesquiera de los derechos 
sociales económicos o culturales existentes (art. 4 xii). En caso de no cumplirse lo anterior, se exige para las víctimas "una justa reparación en el ámbito civil o penal” (art. 11).

Sin embargo, este deber de prevenir no se limita solo a la acción. Vinculado -aunque no lo diga expresamente- a la garantía de no repetición ${ }^{47}$, esta convención llama a combatir la discriminación y la intolerancia desde sus raíces. Es por eso que exige el compromiso de los Estados de "llevar adelante estudios sobre la naturaleza, causas y manifestaciones de la discriminación e intolerancia en sus respectivos países, en los ámbitos local, regional y nacional, y a recolectar, compilar y difundir datos sobre la situación de los grupos o individuos que son víctimas de la discriminación y la intolerancia” (art. 12). Para ello, además, los Estados se comprometen a la cooperación internacional para el intercambio de ideas y de experiencias en estas materias (art. 14).

\subsection{MECANISMOS DE PROTECCIÓN Y SEGUIMIENTO}

También vinculado con la garantía de no repetición, la convención establece unas notables facultades de vigilancia: los llamados "Mecanismos de protección y seguimiento", en su largo art. 15.

Así, para dar seguimiento a la implementación de los compromisos adquiridos, señala que cualquier persona puede presentar ante la Comisión Interamericana de Derechos Humanos denuncias y quejas. Esto sin perjuicio además, de la facultad de cada Estado de reconocer la competencia de esta Comisión "para recibir y examinar las comunicaciones en que un Estado Parte alegue que otro Estado Parte ha incurrido en violaciones de los derechos humanos establecidos en la presente Convención” (art. 15.i) ${ }^{48}$. Igualmente, pueden hacerse consultas y pedir asesorías a este organismo (art. 15.ii). Por último, los Estados también pueden reconocer la competencia de la Corte Interamericana "sobre todos los casos relativos a la interpretación o aplicación de esta Convención” (art. 15.iii). Debe hacerse notar que aquí el Estado podría ser investigado no solo por denuncias de sus propios ciudadanos, sino también si ellas emanan de otros países.

Por otro lado, se ordena establecer un "Comité Interamericano para la Prevención y Eliminación del Racismo, la Discriminación Racial y Todas las Formas de Discriminación e Intolerancia", que se encargará de "monitorear" y "dar seguimiento" a los compromisos asumidos (art. 15 iv), así como de los avances y dificultades que tengan los Estados en esta materia, en virtud de los informes periódicos que se obligan a presentarle, fruto de lo cual, este organismo podrá formularles "recomendaciones" (Art. 15.v).

Es decir, además de la intromisión del Estado, la convención exige la vigilancia de instancias internacionales para evitar actos de discriminación e intolerancia, con lo cual el papel fiscalizador de la autoridad se incrementa aún más.

\footnotetext{
47 Sobre esto, Galdámez (2007) pp. 440 y 453-454; Gómez Robledo (2009) p. 144; Ferrer Mac-Gregor y Pelayo (2012) p. 162.

48 A algo similar alude Cançado, puesto que considera que debe existir una preocupación de toda la comunidad internacional por los derechos humanos, la que debe velar por la observancia de los mismos en todas partes y en cualquier momento, siendo también fundamental en esta tarea la actividad de las ONGs. Por eso llama a establecer un sistema de vigilancia mutua, permanente, universal y homogeneizante de los derechos humanos: CANÇADO. (2006) pp. 42-47, 61-92 y 420-426.
} 
Finalmente, y aplicando el principio pro homine, la convención establece que la legislación interna de un país y otros tratados internacionales priman sobre esta convención, si sus disposiciones son más favorables (art. 16). Y en su art. 20, señala que este instrumento entrará en vigor, para los países firmantes, treinta días después de la segunda ratificación o adhesión en la Secretaría General de la OEA, lo que a la fecha de la presentación de este trabajo aún no había ocurrido.

\subsection{EL DEBER DE PREVENIR}

Como puede apreciarse, el tenor y el espíritu de esta convención están en plena armonía con el deber de prevenir violaciones a los derechos humanos por parte del Estado. En atención a su importancia, se hace necesario indagar brevemente en ella.

La obligación de prevenir "implica el establecimiento e implementación de todas aquellas medidas de carácter jurídico, político, administrativo y cultural que promuevan la salvaguarda de los derechos humanos y que aseguren que las eventuales violaciones a los mismos sean efectivamente consideradas y tratadas como un hecho ilícito" ${ }^{29}$.

Lo anterior ha sido desarrollado por vía jurisprudencial ${ }^{50}$, derivándose del deber de "garantizar" los derechos humanos (art. $1^{\circ}$ de la Convención) ${ }^{51}$. Correspondería llevarla a cabo a todas las autoridades en cada país ${ }^{52}$, pues no basta con la mera existencia de una normativa interna, sino que se exigen acciones directas o positivas por parte del Estado ${ }^{53}$, lo cual debe vincularse, según se ha dicho, con la garantía de no repetición.

\footnotetext{
49 Castilla (2011) p. 156, cursivas nuestras.
}

50 Casi todos los fallos aluden a este deber referido a derechos particulares (vida, torturas, desapariciones forzadas, detenciones ilegales, discriminación contra la mujer, discriminaciones o violencia de género, etc.). Sin embargo, el deber general de prevenir las violaciones a los derechos humanos está muy desarrollado en la jurisprudencia de los últimos años. Entre otros, en Caso González y otras ("Campo Algodonero") vs. México (2009) párr. 236; Caso Garibaldi vs. Brasil (2009), párr. 112; Caso Anzualdo Castro vs. Perú (2009), párr. 62; Caso Escher y otros vs. Brasil (2009), párr. 194; Caso Perozo y otros vs. Venezuela (2009), párr. 118, 127, 160-161, 168, 288 y 362; Caso Ríos y otros vs. Venezuela (2009), párr. 107, 112, 116, 149 y 334; Caso Gomes Lund y otros ("Guerrilha do Araguaia”) vs. Brasil (2010), párr. 140 y 144; Caso Vélez Loor vs. Panamá (2010), párr. 286; Caso Fontevecchia y D’Amico vs. Argentina (2011), párr. 85; Caso Familia Barros vs. Venezuela (2011), párr. 47, 116, 123 y 174; Caso Masacre de Santo Domingo vs. Colombia (2012), párr. 156 y 189; Caso Castillo González y otros vs. Venezuela (2012), párr. 122, 128129, 180 y 184; Caso Masacres de El Mozote y lugares aledaños vs. El Salvador (2012), párr. 144 y 244; Caso Nadege Dorzema y otros vs. República Dominicana (2012), párr. 183, 184, 266 y 274; Caso Vélez Restrepo y Familiares vs. Colombia (2012), párr. 186-189, 192 y 203-204; Caso Pueblo Indigena Kichwa de Sarayaku vs. Ecuador (2012), párr. 245; Caso Forneron e hija vs. Argentina (2012), párr. 131; Caso Pacheco Teruel y otros vs. Honduras (2012), párr. 92 y 104; Caso González Medina y familiares vs. República Dominicana (2012), párr. 127; Caso Artavia Murillo y otros (Fecundación in vitro) vs. Costa Rica (2012) párr. 334; Caso Familia Pacheco Tineo vs. Bolivia (2013) párr. 265 y 269; Caso Luna López vs. Honduras (2013) párr. 118, 120, 123-125, 137, 153, 156 y 234; Caso Suárez Peralta vs. Ecuador (2013) párr. 93, 129, 132, 153 y 195; Caso Gelman vs. Uruguay. Supervisión de Cumplimiento de Sentencia (2013) párr. 72; Caso Hermanos Landaeta Mejías y Otros vs. Venezuela (2014) párr. 181,183-184, 208, 214, 218, 270 y 271; Caso de Personas Dominicanas y Haitianas Expulsadas vs. República Dominicana (2014) párr. 461; Caso Véliz Franco y otros vs. Guatemala (2014) párr. 132, 135-137, 142, 148, 155-157, 185 y 260; y Caso Defensor de Derechos Humanos y otros vs. Guatemala (2014) párr. 139, 140, 141 y 143.

51 Ferrer Mac-Gregor y Pelayo (2012) p. 154.

52 Carbonell (s/f) pp. 69-70; García Ramírez (2011) pp. 143-144; Cançado (2006) pp. 201-210; Ferrer Mac-Gregor y Pelayo (2012) pp. 154-159; Castilla (2011), pp. 154-156.

53 Ferrer Mac-Gregor y Pelayo (2012) pp. 154-158; Galdámez (2007) p. 454; Cançado (2006) pp. 201-204. 
Todo lo dicho hace que pueda surgir -como ocurre en esta convención- la obligación de suprimir no solo normas, sino también prácticas de cualquier especie que violen, obstaculicen o desconozcan estos derechos, razón por la cual, mientras sigan vigentes las normas o las prácticas contrarias, subsistiría el incumplimiento ${ }^{54}$ y la responsabilidad internacional del Estado.

Por eso -y su coincidencia con la convención analizada resulta manifiesta- no solo sería lícito adoptar "medidas positivas generales" ${ }^{55}$, dirigidas a toda la población, sino además, "[1]a estrategia de prevención debe ser integral, es decir, debe prevenir los factores de riesgo y a la vez fortalecer las instituciones para que puedan proporcionar una respuesta efectiva" 56 ante violaciones a los derechos humanos. O como también se ha dicho: "En caso de que existan elementos culturales que obstaculicen el pleno goce y garantía de los derechos, el Estado deberá adoptar medidas para su remoción. Este aspecto de la obligación es particularmente exigible cuando hay grupos que ven constantemente violados sus derechos humanos por razones culturales. En estos casos, el Estado debe realizar una revisión cuidadosa de la manera en que opera la sociedad y un diseño de políticas conducentes para el logro del objetivo de hacer efectivos, para todos los individuos, el goce y ejercicio de los derechos humanos [... E]l deber de protección abarca todas aquellas medidas de carácter jurídico, político, administrativo y cultural que promuevan la salvaguarda de los derechos humanos" $" 57$.

El objetivo final es que se impidan las violaciones a estos derechos, "por parte de cualquier persona, pública o privada, individual o colectiva, física o jurídica" 58 , siendo el Estado responsable internacionalmente por omisión, si no ha puesto la debida diligencia para impedir dichas violaciones y estas hayan sido evitables ${ }^{59}$. Ello, porque la protección de los derechos humanos debiera ser erga omnes ${ }^{60}$.

Como puede apreciarse sin mayor dificultad, la convención contra la discriminación y la intolerancia viene a plasmar con mucha fuerza en su normativa este deber de prevenir, para lo cual se hace necesaria una amplia y constante intervención de la autoridad local, así como de instancias internacionales. Es por eso que se advertía del notable cambio de perspectiva que se aprecia aquí respecto del papel que se le exige al Estado en los documentos que protegen la libertad de expresión.

\section{SUS POSIBLES EFECTOS SOBRE LA LIBERTAD DE EXPRESIÓN}

Como resulta plausible, la libertad de expresión (y también la libertad de educación y de conciencia, si bien no se analizan aquí) podría ser uno de los derechos más afectados con

\footnotetext{
54 Carbonell (s/f) pp. 68-69.

55 Ferrer Mac-Gregor y Pelayo (2012) p. 155. Para estas ideas, ibid, pp. 155-158.

56 Ferrer Mac-Gregor y Pelayo (2012) p. 157. Para estas ideas, ibid, pp. 159-161.

57 Ferrer Mac-Gregor y Pelayo (2012) p. 156, cursivas nuestras. Para esta idea, ibid, pp. 155-158.

58 Ferrer Mac-Gregor y Pelayo (2012) p. 154.

59 Vásquez y Serrano (2011) pp. 145-146; Ferrer Mac-Gregor y Pelayo (2012) pp. 159-161; Cançado (2006) pp. 241-244, 248 y 264-266; García Ramírez (2011) p. 143.

60 CANÇADo (2006) pp. 244-248. Sobre este efecto erga omnes, puede consultarse HitTers (2013) pp. 695-710.
} 
esta normativa, pues bastaría que alguien se sintiera pasado a llevar por la razón que fuese en atención a las opiniones o conductas de otro, para alegar, en virtud de estos criterios tan amplios, estar siendo discriminado o ser víctima de intolerancia y fundamentar su reclamo en la normativa o jurisprudencia que más le convenga gracias al principio pro homine.

Sin embargo, lo anterior haría imposible el debate, pues de aplicar estas disposiciones, podría sancionarse civil o penalmente a algunos o incluso a todos los participantes ${ }^{61}$.

Ahora bien, al margen de la materia regulada, un aspecto fundamental del cual quisiéramos dejar constancia, es el profundo cambio que a nuestro juicio se observa en el enfoque general propuesto en esta última convención referida a la discriminación y la intolerancia, respecto del existente en los documentos anteriores que tutelan la libertad de expresión.

En efecto, resulta claro que en razón de considerarlo un derecho fundamental para el sistema democrático ${ }^{62}$, los documentos anteriores ${ }^{63}$, así como la jurisprudencia de los fallos atingentes al tema ${ }^{64}$, defienden una concepción sumamente amplia de la libertad de expresión, protegiéndola incluso más que otros instrumentos internacionales ${ }^{65}$. Lo anterior explica por qué son férreos detractores de cualquier tipo de censura previa ${ }^{66}$, para lo cual limitan expresa y taxativamente las posibilidades de intervención del Estado. En consecuencia, ellos parten de un supuesto de libertad, tanto para expresar como para conocer las diferentes opiniones que puedan existir sobre cualquier materia, encontrándose ambas dimensiones además, unidas indisolublemente.

Por el contrario, en esta última convención se parte desde una óptica centrada en la vigilancia, con el objetivo no solo de castigar, sino también de prevenir violaciones a los derechos humanos, exigiendo una regulación y fiscalización que podrían tornarse asfixiantes, no solo por parte del Estado y los organismos internacionales de tutela tradicionales (Corte y Comisión), sino también por medio del Comité Interamericano contra la discriminación y la intolerancia. Ello, tanto con el fin de "prevenir, eliminar, prohibir y sancionar [...] todos los actos y manifestaciones de discriminación e intolerancia" (art. 4), como para dar "seguimiento a la implementación de los compromisos adquiridos" por los Estados (art. 15), lo que además debe vincularse a la garantía de no repetición.

Por eso, si se hace un paralelo entre las diferentes actuaciones que podría llevar a cabo el Estado con el fin de prevenir violaciones a los derechos humanos ya mencionadas ${ }^{67}$ y lo establecido en esta última convención, indicando el lugar de su texto donde se plas-

\footnotetext{
${ }^{61}$ Como ya se mencionó en su momento, estas ideas sobre el diálogo son expresadas en el Caso Kimel vs. Argentina (2008) párr. 88; Caso La Última Tentación de Cristo (Olmedo Bustos y otros) vs. Chile (2001) párr. 69; Caso Ivcher Bronstein vs. Perú (2001) párr. 152; y Caso Ricardo Canese vs. Paraguay (2004) párr. 83.

62 OC-5/85, párr. 41-45, 54, 69, 70 y 76.

63 Sobre todo en la $O C-5 / 85$, párr. 50.

${ }^{64}$ Salvo algunos más recientes, en que se miran con más beneplácito las sanciones penales posteriores, según se comentará más adelante.

65 "L]as garantías de la libertad de expresión contenidas en la Convención Americana fueron diseñadas para ser las más generosas y para reducir al minimum las restricciones a la libre circulación de las ideas” (OC-5/85, párr. 50). Ideas similares en párr. 51-52.

66 Declaración de Principios Sobre la Libertad de Expresión, párr. 4 y principios 1, 5, 7, 9; Declaración de Chapultepec, párr. 8 y 14 y principio 5; OC-5/85, párr. 29, 33, 35, 38, 39, 54 y 70.

67 Véase supra, 3.4.
} 
marían dichas actuaciones, la regulación y fiscalización que ella establece podría aplicarse a normas y prácticas (art. 1), y conllevar la adopción de medidas jurídicas, políticas, administrativas y culturales (Preámbulo en general y arts. 5, 6 y 7) para impedir o sancionar conductas que violen, obstaculicen o desconozcan estos derechos (Preámbulo, párr. 4 y 12 y arts. 4 y 11). Para ello, luego de estudiar cómo funciona la sociedad, habría que hacer estudios sobre la naturaleza, causas y manifestaciones de la discriminación e intolerancia (art. 12), para generar un conjunto de medidas positivas generales y políticas integrales de prevención que pueden afectar a toda la población (Preámbulo, párr. 9, 10 y 12 y arts. 4 5, 6 y 7), con el fin de eliminar factores de riesgo, mediante la remoción de los elementos culturales estimados discriminadores o intolerantes, por ejemplo, en la educación (Preámbulo, párr. 12 y art. 4 x). De ahí que este deber del Estado de vigilar y castigar deba extenderse a cualquier ámbito de la esfera pública o privada que apoye, promueva o financie hechos considerados ilícitos (art. 4 i), lo que incluye su publicación, circulación o diseminación, por cualquier forma y/o medio de comunicación, incluida la Internet (art. 4 ii).

Ahora bien, si se recuerda lo establecido a propósito de la libertad de expresión, este cúmulo de medidas tendientes a evitar actos de discriminación e intolerancia, podrían originar muy bien un "abuso de controles oficiales" 68 , un conjunto de "condicionamientos previos" ${ }^{\prime}$, o incluso "la tentación del control y de la regulación coaccionante"70 a su respecto, con lo cual parece imposible que dicha libertad de expresión no pueda verse seriamente restringida, o incluso casi anulada por las exigencias consagradas en esta última convención.

En efecto, entre estas medidas y resguardos anticipados que exige la convención contra la discriminación y la intolerancia y la censura previa -ya sea abierta, encubierta o indirecta ${ }^{71}$ - no hay más que un paso $^{72}$. Pero debe recordarse que la censura previa "es siempre incompatible con la plena vigencia de los derechos enumerados por el artículo 13 [de la Convención Americana...] En esta materia toda medida preventiva significa, inevitablemente, el menoscabo de la libertad garantizada por la Convención"73, razón por la cual hay que "reducir al mínimum las restricciones a la libre circulación de las ideas"74.

68 Convención Americana de Derechos Humanos, art. 13.3.

69 Declaración de Principios Sobre la Libertad de Expresión, No 7.

70 Declaración de Chapultepec, párr. 14.

71 Véase la jurisprudencia citada en la nota 14.

72 De ahí que la Corte haya sido clara al expresar su total repudio a la intervención de la autoridad a fin de limitar este derecho a priori, como son "la censura previa, el secuestro o la prohibición de publicaciones y, en general, todos aquellos procedimientos que condicionan la expresión o la difusión de información al control gubernamental" (OC-5/85, párr. 54).

73 OC-5/85, párr. 38 y Declaración de Principios Sobre la Libertad de Expresión, No 5 . Y como refuerza la jurisprudencia de la Corte, salvo en los casos de censura previa cuyo objetivo es la protección moral de la infancia y la adolescencia, "En todos los demás casos, cualquier medida preventiva implica el menoscabo a la libertad de pensamiento y de expresión" (Caso "La Última Tentación de Cristo" (Olmedo Bustos y otros) vs. Chile (2001), párr. 70), razón por la cual se produce "una violación radical tanto del derecho de cada persona a expresarse como del derecho de todos a estar bien informados, de modo que se afecta una de las condiciones básicas de una sociedad democrática" (Caso Vélez Restrepo y familiares vs. Colombia (2012) párr. 139).

74 OC-5/85, párr. 50. Ideas similares en ibid, párr. 36, 46 y 54. Por su parte, la jurisprudencia a este respecto es abundante: Caso Palamara Iribarne vs. Chile (2005), párr. 68 y 83; Caso Ivcher Bronstein vs. Perú (2001), párr. 152; Caso Usón Ramírez vs. Venezuela (2009), párr. 47-48; Caso Perozo y otros vs. Venezuela (2009), párr. 117; 
Es precisamente a esto a lo que con tanto ahínco se oponen los documentos y la jurisprudencia atingentes a la libertad de expresión, según se ha comentado. De hecho, ellos únicamente aceptan una intervención posterior ante posibles abusos y no preventiva $-\mathrm{y}$ por tanto, de censura-, como en la última convención. En realidad, y volviendo al deber de prevenir, tal como está concebido este derecho, la actual forma de ejercer la libertad de expresión podría incluso considerarse una conducta cultural que debiera ser erradicada.

Incluso, esta opresiva fiscalización podría originar un velado monopolio público respecto de lo que estaría permitido expresar y conocer, situación abiertamente condenada por la $O C-5 / 85^{75}$.

Todo lo anterior es lo que nos lleva a pensar, como se advertía, que pareciera existir un profundo cambio de perspectiva en esta última convención respecto de la libertad de expresión. Solo eso parece explicar que ella no se conforme con las ya existentes responsabilidades ulteriores (y solo ulteriores ${ }^{76}$ ) fruto de eventuales abusos de este derecho -incluso penales-, sino que llame insistentemente a prevenir actos de discriminación o intolerancia. Pero además, y desde una mirada más procedimental, debe recordarse que de acuerdo con los documentos que defienden la libertad de expresión, las eventuales responsabilidades debían ser restrictivas, no amplias (o incluso amplísimas) como en este caso.

En efecto, las claras restricciones a las libertades de expresión y de información consagradas en esta convención (incluso por Internet), no cumplen con los requisitos ni de forma ni de fondo que exigen la Convención Americana (art. 13), la OC-5/85, ni otros documentos analizados ${ }^{77}$. Como se recordará, desde una óptica formal, las posibles causales deben ser establecidas por la ley, de manera previa, en razón de fines legítimos, siempre que estas restricciones sean necesarias y no simplemente "útiles" para lograr esos fines, que estén consagradas de forma expresa y taxativa ${ }^{78}$; y desde una perspectiva de fondo, debe usarse la alternativa que restrinja menos este derecho ${ }^{79}$, en virtud del principio pro homine,

Caso Kimel vs. Argentina (2008), párr. 54 y 56; Caso Apitz Barbera y otros ("Corte Primera de lo Contencioso Administrativo") vs. Venezuela (2008), párr. 131; Caso Tristán Donoso vs. Panamá (2009), párr. 110; Caso Ricardo Canese vs. Paraguay (2004), párr. 96; Caso Herrera Ulloa vs. Costa Rica (2004), párr. 120, 121 y 123; y Caso Fontevecchia y D’Amico vs. Argentina (2011), párr. 89-90.

75 "[T]ampoco sería admisible que, sobre la base del derecho a difundir informaciones e ideas, se constituyeran monopolios públicos o privados sobre los medios de comunicación para intentar moldear la opinión pública según un solo punto de vista” (OC-5/85, párr. 33).

76 OC-5 En efecto, las claras restricciones a las libertades de expresión y de información consagradas en esta convención (incluso por Internet), no cumplen con los requisitos ni de forma ni de fondo que exigen la Convención Americana (art. 13), la $O C-5 / 85$, ni otros documentos analizados. Como se recordará, desde una óptica formal, las posibles causales deben ser establecidas por la ley, de manera previa, en razón de fines legítimos, siempre que estas restricciones sean necesarias y no simplemente "útiles" para lograr esos fines, que estén consagradas de forma expresa y taxativa; y desde una perspectiva de fondo, debe usarse la alternativa que restrinja menos este derecho, en virtud del principio pro homine, y teniendo siempre en cuenta los necesarios mecanismos de ponderación entre los derechos en pugna./85, párr.41. Véanse notas 18, 30, 89 y 95.

77 OC-5/85, párr. 39, 40, 46 y 79; Declaración de Principios Sobre la Libertad de Expresión, No 10. La Declaración de Chapultepec no aborda esta cuestión.

78 OC-5/85, párr. 39 y 40.

79 Como sostiene la Comisión Interamericana en el Caso Herrera Ulloa vs. Costa Rica (2004): "Las restricciones a la libertad de expresión deben estar orientadas a satisfacer un interés público imperativo. Entre varias opciones debe 
y teniendo siempre en cuenta los necesarios mecanismos de ponderación ${ }^{80}$ entre los derechos en pugna.

Todos estos requisitos se ven completamente modificados por la presente convención, pues desde una perspectiva formal, las causales pueden ser establecidas por normas y sentencias nacionales o internacionales -o sea, casi por cualquier normativa-. También podrían ser determinadas a posteriori, dados los amplísimos conceptos utilizados, todo lo cual hace fácil y hasta tentador abusar de dichas causales por el poder de turno. Por otro lado, ellas resultan sumamente indeterminadas, tanto por las generosas definiciones de discriminación e intolerancia establecidas, por el carácter abierto y no taxativo de las causales de discriminación, en razón de ser conceptos "democráticos dinámicos", y finalmente, debido a las dúctiles normas de interpretación existentes en el sistema interamericano. Por último, se establecen medidas tremendamente generales y amplias para evitar la discriminación y la intolerancia (prevenir, eliminar, prohibir, sancionar, normas, prácticas, manifestaciones, etc.), y no de forma expresa y taxativa, como se exigía antes.

Por otro lado, y desde una perspectiva de fondo, las medidas que exige la convención, además de ser muchas de ellas previas al acto supuestamente ilícito, son demasiado generales y no casuísticas, como exige el criterio de ponderación. Finalmente, respecto de los problemas a que puede dar origen la aplicación del principio pro homine ellos se comentarán en seguida.

Ahora bien, la perentoria exigencia de tener en cuenta las condiciones de forma y fondo señaladas ha sido ratificada por la propia Corte, sobre todo al mencionar los requisitos exigibles para aplicar sanciones penales ulteriores en caso de haber un abuso de la libertad de expresión (con lo cual, a nuestro juicio, de paso estaría deslegitimando las medidas previas y generales que establece la última convención): "La necesidad de utilizar la vía penal para imponer responsabilidades ulteriores al ejercicio del derecho a la libertad de expresión se debe analizar con especial cautela y dependerá de las particularidades de cada caso. Para ello, se deberá considerar el bien que se pretende tutelar, la extrema gravedad de la conducta desplegada por el emisor de aquellas, el dolo con que actuó, las características del daño injustamente causado, las características de la persona cuyo honor o reputación se pretende salvaguardar, el medio por el cual se pretendió causar el daño y otros datos que pongan de manifiesto la absoluta necesidad de utilizar, en forma verdaderamente excepcional, medidas penales. En todo momento la carga de la prueba debe recaer en quien formula la acusación" $"$.

escogerse aquella que restrinja en menor escala el derecho protegido, y la restricción debe ser proporcionada al interés que la justifica" (párr. 101.1 b)).

80 "La solución del conflicto que se presenta entre ambos derechos requiere de una ponderación entre los mismos, a través de un juicio de proporcionalidad, para lo cual deberá examinarse cada caso, conforme a sus características y circunstancias, a fin de apreciar la existencia e intensidad de los elementos en que se sustenta dicho juicio" (Caso Mémoli vs. Argentina (2013), párr. 127).

${ }^{81}$ Caso Usón Ramírez vs. Venezuela (2009) párr. 74. Casi con las mismas palabras en Caso Kimel vs. Argentina (2008) párr. 78 y Caso Mémoli vs. Argentina (2013) párr. 139. En todos (notas 59, 57 y 259) se cita jurisprudencia europea, lo que avala el hecho de estar frente a un 'giro' de la Corte respecto de las sanciones penales ulteriores. 
Es por eso que todo lo dicho hasta aquí, nos lleva a conjeturar que podríamos estar en presencia de una evolución en el sistema interamericano, desde una situación de amplia protección a la libertad de expresión, hacia otra de mayor tutela de la autoridad a fin de evitar la discriminación y la intolerancia.

La anterior conjetura se basa en que si primara la libertad de expresión (en razón de ser fundamental para la democracia, según declaran los documentos y jurisprudencia analizados), llegado el momento de aplicar el principio pro homine, debiera tener preferencia la norma que mejor proteja este derecho (es decir, la Convención Americana) sobre cualquier otra, sea regional o universal -como declara expresamente la OC 5/85 $5^{2}$, lo cual también tendría que incluir a la Convención Interamericana contra Toda Forma de Discriminación e Intolerancia. Mas al tenor de esta última, y dadas sus notables restricciones a la libertad de expresión, el principio pro homine pareciera haber pivotado, y estar ahora aplicándose en favor de la no discriminación y de la tolerancia, pues en caso contrario, muchas de esas restricciones que establece no tendrían sentido, o al menos, serían impracticables, pues siempre serían superadas por las normas en pro de la libertad de expresión ${ }^{83}$.

Desde otra perspectiva complementaria, también parece ilógico que las disposiciones de esta nueva convención no estén en armonía con el actual sentir de la Corte (sería, por decirlo así, una ingenuidad de sus promotores), pues dadas las amplísimas facultades interpretativas de este tribunal, en caso contrario, podría sin muchas dificultades modificarlas, o sencillamente no aplicarlas en absoluto, al ser la intérprete final de estos tratados.

De hecho, tal vez este posible cambio de énfasis explique en parte la evolución de la jurisprudencia de la Corte en los últimos años, que la ha llevado a ver con mejores ojos las posibles sanciones penales ulteriores que puede originar un abuso de la libertad de expresión $^{84}$. Igualmente, el mismo fenómeno podría fundamentar la mayor importancia que se ha dado en fallos más recientes (sobre todo desde el año 2009) al deber de prevenir ${ }^{85}$, no ya la violación de ciertos derechos fundamentales específicos, sino la globalidad de los contenidos en la Convención Americana, todo lo cual exige una notable intervención de

\footnotetext{
82 "[T]al método no podría emplearse nunca para incorporar a la Convención criterios restrictivos que no se desprendan directamente de su texto, por más que estén presentes en cualquier otro tratado internacional" (OC-5/85, párr. 51). Por eso, "para que sean compatibles con la Convención las restricciones deben justificarse según objetivos colectivos que, por su importancia, preponderen claramente sobre la necesidad social del pleno goce del derecho que el artículo 13 garantiza y no limiten más de lo estrictamente necesario el derecho proclamado en el artículo 13" (ibid, párr. 46). Además, "La necesidad de proteger los derechos que pudieran verse afectados por un ejercicio abusivo de la libertad de expresión, requiere la debida observancia de los limites fijados a este respecto por la propia Convención" (Caso Fontevecchia y D’Amico vs. Argentina (2011), párr. 50). Ideas similares en Caso Kimel vs. Argentina (2008), párr. 56.

83 OC-5/85, párr. 38, 50 y 51. Por eso también contraviene la Convención "todo acto del poder público que implique una restricción al derecho de buscar, recibir y difundir informaciones e ideas, en mayor medida o por medios distintos de los autorizados por la misma Convención; y todo ello con independencia de si esas restricciones aprovechan o no al gobierno" (ibid, párr. 55).

84 Caso Mémoli vs. Argentina (2013) párr. 126, 133, 137-139, 144, 148-149, 204 y 217; Caso Fontevecchia y D’Amico vs. Argentina (2011) párr. 53 y 55 y de manera más indirecta, párr. 49; Caso Kimel vs. Argentina (2008) párr. 71, 75 y 76-78; Caso Usón Ramírez vs. Venezuela (2009) párr. 73-74; y Caso Tristán Donoso vs. Panamá (2009) párr. 118 y 120.

85 Véase la nota 50.
} 
la autoridad, a fin de no hacer caer el Estado en responsabilidad internacional. Por último, análogas razones parecieran estar en la base de su mayor preocupación por lograr un mejor equilibrio de la libertad de expresión con la honra, el honor y la vida privada ${ }^{86}$.

Ahora bien, no podemos dejar de advertir que con estas tan amplias exigencias en pro de la no discriminación y de la tolerancia, de la mano del deber de prevenir y de la garantía de no repetición, el propio ordenamiento jurídico podría acabar convirtiéndose en el peor instrumento intimidatorio para la libertad de expresión, que era justamente lo que querían evitar los defensores de este derecho ${ }^{87}$. Como ha señalado la propia jurisprudencia de la Corte, si bien, nuevamente referido solo a sanciones posteriores, no a actuaciones previas de la autoridad: "el ejercicio efectivo de la libertad de expresión implica la existencia de condiciones y prácticas sociales que lo favorezcan. Es posible que esa libertad se vea ilegítimamente restringida por actos normativos o administrativos del Estado o por condiciones de facto que coloquen, directa o indirectamente, en situación de riesgo o mayor vulnerabilidad a quienes la ejerzan o intenten ejercerla, por actos u omisiones de agentes estatales o de particulares. En el marco de sus obligaciones de garantía de los derechos reconocidos en la Convención, el Estado debe abstenerse de actuar de manera tal que propicie, estimule, favorezca o profundice esa vulnerabilidad y ha de adoptar, cuando sea pertinente, medidas necesarias y razonables para prevenir o proteger los derechos de quienes se encuentren en tal situación, así como, en su caso, investigar hechos que los perjudiquen" ${ }^{\text {". }}$.

O como ha dicho en otro fallo: "La Corte ya se ha referido en otros casos al efecto intimidante en el ejercicio de la libertad de expresión que puede causar el temor a verse sometido a una sanción penal o civil innecesaria o desproporcionada en una sociedad democrática, que puede llevar a la autocensura tanto a quien le es impuesta la sanción como a otros miembros de la sociedad"89.

Es por eso que los anteriores documentos se han opuesto tan férreamente a este intervencionismo de la autoridad, en atención a sus evidentes peligros: Un sistema de control al derecho de expresión en nombre de una supuesta garantía de la corrección y veracidad de la información que la sociedad recibe puede ser fuente de grandes abusos y, en el fondo, viola el derecho a la información que tiene esa misma sociedad"90.

La misma idea ha sido también expuesta de la siguiente manera: "Solo mediante la libre expresión y circulación de ideas, la búsqueda y difusión de informaciones, la posibilidad de indagar y cuestionar, de exponer y reaccionar, de coincidir y discrepar, de dialogar y confrontar, de publicar y transmitir, es posible mantener una sociedad libre" ${ }^{11}$.

\footnotetext{
86 Caso Fontevecchia y D’Amico vs. Argentina (2011) párr. 50; y Caso Kimel vs. Argentina (2008) párr. 56.

87 Como mencionamos al final de supra 2.

88 Caso Vélez Restrepo y familiares vs. Colombia (2012) párr. 189.

89 Caso Norín Catrimán y otros (dirigentes, miembros y activista del pueblo indígena mapuche) vs. Chile (2014) párr. 376. Ideas similares en Caso Vélez Restrepo y familiares vs. Colombia (2012) párr. 189.

90 OC-5/85, párr. 77. Se relaciona con el párr. 55.

91 Declaración de Chapultepec, Preámbulo, párr. 8.
} 
Incluso, de no ser cuidadosos, este deber del Estado de vigilar y castigar, al tenor de esta última convención, podría afectar a la misma institucionalidad democrática, debido a sus estrechos vínculos con la libertad de expresión ${ }^{92}$.

Todo lo dicho hasta aquí significa que el diálogo no puede censurarse en virtud de las posibles ofensas que pueda causar en quienes piensan distinto, ya que semejante actitud conllevaría hacerlo imposible $e^{93}$ y constituye a todas luces una medida desproporcionada ${ }^{94}$. Por eso, tener ciertas convicciones en el ámbito que sea, u oponerse a las de otros -pues la disidencia debe tener derecho a expresarse ${ }^{95}$, siempre en un clima de respeto, no quiere decir que quien ostente cierto punto de vista, "defienda, promueva o incite al odio, la discriminación y la intolerancia" ${ }^{\prime 6}$. Estos males deben ser combatidos, sin lugar a dudas, pero no a costa de terminar convirtiendo en un riesgo para los sujetos defender sus propias convicciones, fruto de la existencia de un orden jurídico que puede tornarse opresivo, eventualmente paranoico y absolutamente contrario al espíritu democrático ${ }^{97}$.

\section{CONCLUSIONES}

Un primer aspecto que puede concluirse luego de este trabajo, es la notable contradicción que existe entre la normativa y jurisprudencia que protegen la libertad de expresión y la convención que busca impedir la discriminación y la intolerancia.

Dicha contradicción resulta manifiesta, pues los primeros establecen una concepción amplia y protectora de la libertad de expresión, limitando notablemente el accionar del Estado, aceptándolo solo de manera ulterior ante eventuales abusos, y con diversas exigencias de forma y fondo. En cambio, la última convención, además de establecer definiciones amplísimas de lo que entiende por discriminación e intolerancia, no se contenta con exigir sanciones ante posibles ilícitos, sino que regula sobre todo y también de forma muy amplia, una serie de mecanismos previos, directos e indirectos, para evitarlos, ignorando además

92 OC-5/85, párr. 70. Por eso "La libertad de expresión se inserta en el orden público primario y radical de la democracia, que no es concebible sin el debate libre y sin que la disidencia tenga pleno derecho de manifestarse" (párr. 69).

93 Véase la nota 26.

94 Sobre la necesidad de la proporcionalidad de las medidas contra la libertad de expresión (siempre posteriores), puede verse: OC-5/85, párr. 36, 46 y 54; Caso Herrera Ulloa vs. Costa Rica (2004), párr. 120, 121 y 123 ; Caso Mémoli vs. Argentina (2013), párr. 126, 127 y 131; Caso Tristán Donoso vs. Panamá (2009), párr. 56; Caso Palamara Iribarne vs. Chile (2005) párr. 68, 79 y 85; Caso Vélez Restrepo y familiares vs. Colombia (2012) párr. 139; y Caso Kimel vs. Argentina (2008), párr. 83.

95 OC-5/85, párr. 69; Declaración de Chapultepec, Preámbulo, párr. 8.

96 Convención Interamericana contra Toda Forma de Discriminación e Intolerancia, art. 4.

${ }_{97}$ No nos parece que las radicales medidas que promueve la Convención contra la discriminación y la intolerancia apunten a lo que pretende evitar el art. 13.5 de la Convención Americana: "Estará prohibida por la ley toda propaganda en favor de la guerra y toda apología del odio nacional, racial o religioso que constituyan incitaciones a la violencia o cualquier otra acción ilegal similar contra cualquier persona o grupo de personas, por ningún motivo, inclusive los de raza, color, religión, idioma u origen nacional". Tampoco estimamos que sea suficiente invocar el art. 32.2 de la Convención Americana: "Los derechos de cada persona están limitados por los derechos de los demás, por la seguridad de todos y por las justas exigencias del bien común, en una sociedad democrática”. Es por eso que creemos que el punto de partida de esta última convención es radicalmente distinto del que asumen los documentos que defienden la libertad de expresión. 
esos requisitos de forma y fondo anteriormente establecidos, al menos en lo que respecta a la libertad de expresión.

En segundo lugar estas medidas anticipadas que buscan evitar la discriminación y la intolerancia -vinculadas al deber de prevenir y a la garantía de no repetición- pueden muy bien originar prácticas de censura previa, violando así la prohibición a su respecto contenida en la Convención Americana de Derechos Humanos, los demás documentos analizados y la jurisprudencia constante de la Corte.

De ocurrir lo anterior, el ordenamiento jurídico podría transformarse en el mayor obstáculo para la libertad de expresión - posibilidad condenada expresamente por los documentos y sentencias que tutelan este derecho-, al inhibir la difusión de las ideas, generando también una autocensura de diversos miembros o sectores de la sociedad. Ello, porque como se ha señalado, bastaría que una persona o grupo se sintiera pasado a llevar por las opiniones, informaciones o noticias manifestadas por el medio que sea, para que sus autores puedan ser sancionados o incluso censurados por ello. Esto sin perjuicio de los posibles efectos que la aplicación de esta convención podría tener en la carga de la prueba, y de los eventuales abusos en que podrían incurrir las supuestas víctimas, en atención a sus definiciones tan amplias, así como debido al uso del principio pro homine, lo cual permitiría justificar la supuesta infracción en la normativa que más convenga a los interesados.

Es por eso que de aplicarse esta convención según su espíritu, a nuestro juicio surgiría una preocupante sombra de duda respecto del futuro de la libertad de expresión en el continente.

En tercer lugar, y como mera conjetura - pues solo se han analizado los derechos en pugna mencionados-, podría estar produciéndose una evolución dentro del sistema interamericano de derechos humanos, desde un principio de libertad, que tutela a posteriori las eventuales infracciones de ciertos derechos, a otra situación que pretende impedir su desconocimiento, anticipándose así a los hechos potencialmente ilícitos. Ello, debido a la cada vez mayor importancia que está adquiriendo el deber que tiene el Estado de prevenir violaciones a los derechos humanos, lo cual se relaciona además, con la garantía de no repetición. Esta evolución también puede explicar la mayor aceptación de la Corte de las sanciones civiles y sobre todo penales ante eventuales abusos de la libertad de expresión, así como su preocupación por lograr un mejor equilibrio con otros derechos.

Sin embargo, resulta indudable que para lograrlo, sería necesario darle un cúmulo de atribuciones al Estado para vigilar y castigar a sus ciudadanos, con lo cual podrían violarse varios otros derechos.

Por eso se advertía que este cambio de perspectiva podía hacer pivotar el principio pro homine, a fin de justificar un mayor intervencionismo estatal, pues en caso contrario (esto es, si se lo aplicara del modo que establecen los documentos atingentes a la libertad de expresión), muchas de las disposiciones de este último tratado, sobre todo las preventivas, serían inaplicables, pues siempre primaría la Convención Americana de Derechos Humanos.

¿Significa lo anterior que la Convención Interamericana contra Toda Forma de Discriminación e Intolerancia estaría, por decirlo de algún modo, derogando parcialmente -o si se prefiere, dejando sin efecto en la práctica- al Pacto de San José de Costa Rica, al menos en lo que respecta a la libertad de expresión? Dadas las dúctiles reglas de interpretación 
del derecho internacional de los derechos humanos utilizadas por la Corte, así como a las amplias posibilidades que ofrece el principio pro homine, el cual permitiría incluso obviar el criterio de jerarquía entre las normas en pugna -y a nuestro juicio, también el de especialidad-, todo dependería de cuál de ambas convenciones sea considerada más protectora de los derechos humanos por este tribunal. Con todo, en caso de darse esta posibilidad, cabe preguntarse si ella resulta legítima.

Finalmente, no puede pasarse por alto el negativo efecto que todo lo dicho hasta aquí podría ocasionar al sistema democrático. Dado que la libertad de expresión es uno de sus pilares fundamentales, de aplicarse en todo su potencial las medidas de censura y sanciones contempladas por esta convención, así como también gracias al efecto reflejo de autocensura que podría originar, las consecuencias para dicho modelo podrían ser de proporciones. Ello, porque se estaría restringiendo el libre y necesario debate que este sistema requiere. Además, el debilitamiento de este derecho podría mitigar y hasta anular la necesaria fiscalización que solo una libertad de expresión fuerte permite hacer a los actos de gobierno; con lo cual, dicha autoridad podría muy bien abusar de sus prerrogativas, ser intolerante con las convicciones opuestas a la suya y discriminar así a quienes piensan distinto o disienten de su modo de ver las cosas. Incluso le sería posible impedir la disidencia o restringirla de acuerdo a una supuesta verdad oficial, usando para ello el poder punitivo del Estado, con lo cual el debate democrático podría hacerse imposible o, peor aún, convertirse en una auténtica parodia, al haberse establecido por la fuerza los parámetros de lo admisible y eventualmente de lo verdadero.

\section{BIBLIOGRAFÍA CITADA}

Aguilar Cavallo, Gonzalo (2012): "El Control de Convencionalidad de los derechos. Comentario a la sentencia de la Corte Suprema de Chile en el caso denominado Episodio Rudy Cárcamo Ruiz de 24.5.12”, Estudios Constitucionales, Año 10 No 2: pp. 717-750.

Aguilar Cavallo, Gonzalo (2009): "La Corte Suprema y la aplicación del Derecho Internacional: un proceso esperanzador”, Estudios Constitucionales, Año 7 (1): pp. 91-136.

Albanese, Susana (s/f), "La fórmula de la cuarta instancia". Disponible en LexisNexis, Lexis No 0003/001051, pp. 1-12 [fecha de consulta: 13 de mayo de 2014].

Amaya Villarreal, Álvaro (2005): "El principio pro homine: interpretación extensiva vs. el consentimiento del Estado", International Law. Revista colombiana de Derecho Internacional, Pontificia Universidad Javeriana, No 5: pp. 337-380.

Cançado Trindade, Antonio A. (2006): El Derecho Internacional de los Derechos Humanos en el siglo XXI, 2a ed. (Santiago, Editorial Jurídica de Chile).

Carbonell, Miguel (s/f): "Introducción general al control de convencionalidad". Disponible en http://biblio.juridicas.unam.mx/libros/7/3271/11.pdf [fecha de consulta: 14 de mayo de 2014] pp. 67-95.

Castilla Juárez, Karlos (2011): “Un nuevo panorama constitucional para el derecho internacional de los derechos humanos en México", Estudios Constitucionales, Año 9 (2) pp. $123-164$ 
Ferrer Mac-Gregor, Eduardo (2011): "Interpretación conforme y control difuso de convencionalidad. El nuevo paradigma para el juez mexicano", en Carbonell, Miguel; SALAZAR, Pedro (EDs.), Derechos humanos; un nuevo modelo constitucional (México, Unam) pp. 339-429.

Ferrer Mac-Gregor, Eduardo y Pelayo Möller, Carlos María (2012): “La obligación de 'respetar' y 'garantizar' los derechos humanos a la luz de la jurisprudencia de la Corte Interamericana”, Estudios Constitucionales, Año 10 (2) pp. 141-192.

Fríes Monleón, Lorena (2012): "El Instituto Nacional de Derechos Humanos en Chile y sus desafíos para avanzar hacia una visión integral en el discurso y práctica de los derechos humanos en Chile", Anuario de Derechos Humanos, vol. 8, pp. 165-171.

Galdámez Zelada, Liliana (2007): "Protección de la víctima, cuatro criterios de la Corte Interamericana de Derechos Humanos: interpretación evolutiva, ampliación del concepto de víctima, daño al proyecto de vida y reparaciones", Revista Chilena de Derecho, vol. 34 (3) pp. 439-455.

García Ramírez, Sergio (2011): "El control judicial interno de convencionalidad”, IUS, Revista del Instituto de Ciencias Jurídicas de Puebla, México, Año V, No 28: pp. 123-159.

Gómez Robledo, Juan Manuel (2009): “La implementación del Derecho Internacional de los Derechos humanos en el ámbito interno: una tarea pendiente", en GarCía RAMírez, Sergio; Castañeda Hernández, Mireya (Coords.), Recepción nacional del Derecho Internacional de los Derechos Humanos y admisión de la competencia de la Corte Interamericana (México, Unam) pp. 127-150.

Hitters, Juan Carlos (2013): “Un avance en el control de convencionalidad. (El efecto "erga omnes» de las sentencias de la Corte Interamericana)", Estudios Constitucionales, Año 11 No 2: pp. 695-710.

Meier García, Eduardo (2011): "Nacionalismo constitucional y Derecho Internacional de los Derechos Humanos", Estudios Constitucionales, Año 9 (2): pp. 329-376.

Nogueira Alcalá, Humberto (2012a): "El uso del derecho convencional internacional de los derechos humanos en la jurisprudencia del Tribunal Constitucional chileno en el período 2006-2010", Revista Chilena de Derecho, vol. 39 No 1: pp. 149-187.

Nogueira Alcalá, Humberto (2012b): "Diálogo interjurisdiccional, control de convencionalidad y jurisprudencia del Tribunal Constitucional en el período 2006-2011”, Estudios Constitucionales, Año 10 No 2: pp. 57-140.

Nogueira Alcalá, Humberto (2012C): "Los desafíos del control de convencionalidad del corpus iuris interamericano para las jurisdicciones nacionales", Boletín Mexicano de Derecho Comparado, Nueva serie, año XLV, núm. 135, septiembre-diciembre: pp. 1167-1220.

Núñez Poblete, Manuel (2011): "Principios metodológicos para la evaluación de los acuerdos aprobatorios de los tratados internacionales de derechos humanos y de las leyes de ejecución de obligaciones internacionales en la misma materia”, Hemiciclo, Revista de Estudios Parlamentarios, Año 2 No 4: pp. 51-81.

Orozco Henríquez, José de Jesús (2011): "Los derechos humanos y el nuevo artículo $1^{\circ}$ constitucional”, IUS, Revista del Instituto de Ciencias Jurídicas de Puebla, Año V, No 28: pp. 85-98. 
VÁsqueZ, Luis Daniel y Serrano, Sandra (2011): "Los principios de universalidad, interdependencia, indivisibilidad y progresividad. Apuntes para su aplicación práctica”, en Carbonell, Miguel, Salazar, Pedro (Coords.), La reforma constitucional en derechos humanos: un nuevo paradigma (México, Unam) pp. 135-165.

\section{DOCUMENTOS INTERNACIONALES CITADOS}

Declaración Americana de Derechos y Deberes del Hombre, 1948.

Convención Americana de Derechos Humanos, 1969.

Opinión Consultiva OC-5/85. La colegiación obligatoria de Periodistas (Arts. 13 y 29 de la Convención Americana de Derechos Humanos), 1985.

Protocolo Adicional a la Convención Americana Sobre Derechos Humanos en Materia de Derechos Económicos, Sociales y Culturales ("Protocolo de San Salvador"), 1988.

Declaración de Chapultepec, 1994.

Declaración de Santiago. Segunda Cumbre de las Américas, 1998.

Declaración de Principios sobre Libertad de Expresión, Comisión Interamericana de Derechos Humanos, 2000.

Carta Democrática Interamericana, 2001.

Carta Social de Las Américas, 2012.

Convención Interamericana contra Toda Forma de Discriminación e Intolerancia, 2014.

Convención Interamericana contra el Racismo, la Discriminación Racial, y Formas Conexas de Intolerancia, 2014.

\section{JURISPRUDENCIA DE LA CORTE INTERAMERICANA DE DERECHOS HUMANOS}

"La Última Tentación de Cristo" (Olmedo Bustos y otros) vs. Chile. Fondo, ReparacioNES Y COSTAS (2005): Sentencia de 5 de febrero de 2001. Serie C No 73.

ivcher Bronstein vs. Perú. Reparaciones y Costas. Sentencia de 6 de febrero de 2001. Serie C No 74.

Herrera Ulloa vs. Costa Rica. Excepciones Preliminares, Fondo, Reparaciones y Costas (2004): Sentencia de 2 de julio de 2004. Serie C No 107.

Ricardo Canese vs. Paraguay. Fondo, Reparaciones y Costas (2004): Sentencia de 31 de agosto de 2004. Serie C No 111.

Palamara Iribarne vs. Chile. Fondo Reparaciones y Costas (2005): Sentencia de 22 de noviembre de 2005. Serie C No 135.

Claude Reyes y otros vs. Chile. Fondo, Reparaciones y Costas (2005): Sentencia de 19 de septiembre de 2006. Serie C No 151.

Chaparro Álvarez y Lapo Íñguez vs. ECUador. Excepciones Preliminares, Fondo, Reparaciones y Costas (2007): Sentencia de 21 de noviembre de 2007. Serie C No 170.

Kimel vs. Argentina (Fondo, Reparaciones y Costas) (2008): Sentencia de 2 de mayo de 2008. Serie C No 177. 
Apitz Barbera y otros (“Corte Primera de lo Contencioso Administrativo") Vs. Venezuela. Excepción Preliminar, Fondo, Reparaciones y Costas (2008): Sentencia de 5 de agosto de 2008. Serie C No 182.

VAlle Jaramillo Y otros Vs. Colombia. Fondo, Reparaciones y Costas. Sentencia de 27 de noviembre de 2008. Serie C No 192.

Tristán Donoso vs. Panamá. Excepción Preliminar, Fondo, Reparaciones y Costas (2009): Sentencia de 27 de enero de 2009. Serie C No 193.

Ríos y otros vs. Venezuela. Excepciones Preliminares, Fondo, Reparaciones y Costas (2009): Sentencia de 28 de enero de 2009. Serie C No 194.

Perozo y otros vs. Venezuela. Excepciones Preliminares, Fondo, Reparaciones y Costas (2009): Sentencia de 28 de enero de 2009. Serie C No 195.

ESCHER Y OtRos VS. BRASIL. EXCEPCIONES PRELIMINARES, FONDO, REPARACIONES Y COSTAS (2009): Sentencia de 6 de julio de 2009. Serie C No 200.

Anzualdo Castro vs. Perú. Excepción Preliminar, Fondo, Reparaciones y Costas (2009): Sentencia de 22 de septiembre de 2009. Serie C No 202.

Garibaldi Vs. Brasil. Excepciones Preliminares, Fondo, Reparaciones y Costas (2009): Sentencia de 23 de septiembre de 2009. Serie C No 203.

González y otras ("CAmpo Algodonero") vs. MÉXico. EXCEPCión Preliminar, Fondo, RepaRACIONES Y COSTAS (2009): Sentencia de 16 de noviembre de 2009. Serie C No 205.

Usón Ramírez vs. Venezuela. Excepción Preliminar, Fondo, Reparaciones y Costas (2009): Sentencia de 20 de noviembre de 2009. Serie C No 207.

Manuel Cepeda VARGas vs. Colombia Excepciones preliminares, Fondo, Reparaciones y Costas (2010): Sentencia del 26 de mayo de 2010. Serie No 213.

Vélez Loor vs. Panamá. Excepciones Preliminares, Fondo, Reparaciones y Costas (2010): Sentencia de 23 de noviembre de 2010. Serie C No 218.

Gomes Lund y otros (“Guerrilha do Araguaia”) vs. Brasil. ExCEPCIONES Preliminares, Fondo, Reparaciones Y Costas (2010): Sentencia de 24 de noviembre de 2010. Serie C No 219.

FAMilia BARRos vs. VENEZUELA. Fondo, REPARACIONES Y COSTAS (2011): Sentencia de 24 de noviembre de 2011. Serie C No 237.

FonteVecChia Y D'Amico Vs. ARgentina. Fondo, Reparaciones y Costas (2011): Sentencia de 29 de noviembre de 2011. Serie C No 238.

González Medina y familiares vs. República Dominicana. ExcepCiones Preliminares, Fondo, Reparaciones y Costas (2012): Sentencia de 27 de febrero de 2012 Serie C No 240.

Pacheco Teruel y otros vs. Honduras. Fondo, Reparaciones y Costas (2012): Sentencia de 27 de abril de 2012. Serie C No 241.

Forneron e hija Vs. Argentina. Fondo, Reparaciones y Costas (2012): Sentencia de 27 de abril de 2012. Serie C No 242.

Pueblo IndígENa KICHWA DE SARAYAKU VS. ECUAdOR. Fondo Y REPARACIONES (2012): Sentencia de 27 de junio de 2012. Serie C No 245.

VÉlez Restrepo y familiares Vs. Colombia. EXCEPCiÓn preliminar, Fondo, Reparaciones Y Costas (2012): Sentencia de 3 de septiembre de 2012. Serie C No 248.

Uzcátegui y otros vs. Venezuela. Fondo y Reparaciones (2012): Sentencia de 3 de septiembre de 2012. Serie C No 249. 
Nadege Dorzema y otros vs. República Dominicana. Fondo Reparaciones y Costas (2012): Sentencia de 24 de octubre de 2012. Serie C No 251.

Masacres de El Mozote y lugares aledaños vs. El SalVador. Fondo, Reparaciones y Costas (2012): Sentencia de 25 de octubre de 2012. Serie C No 252.

Gudiel Álvarez y otros ("Diario Militar") vs. Guatemala. Fondo, Reparaciones y Costas (2012): Sentencia de 20 de noviembre de 2012. Serie C No 253.

Castillo GonzÁlez y otros vs. Venezuela. Fondo (2012): Sentencia de 27 de noviembre de 2012. Serie C No 256.

Masacre de Santo Domingo vs. Colombia. Excepciones Preliminares, Fondo y ReparacioNES (2012): Sentencia de 30 de noviembre de 2012. Serie C No 259.

Gelman vs. URuguay. Supervisión de Cumplimiento de Sentencia (2013): Resolución de la Corte Interamericana de Derechos Humanos 20 de marzo de 2013.

Mémoli vs. Argentina. Excepciones preliminares, Fondo, Reparaciones Y Costas (2013): Sentencia de 22 de agosto de 2013. Serie C No 265.

Luna López vs. Honduras. Fondo, Reparaciones y Costas (2013): Sentencia de 10 de octubre de 2013. Serie C No 269.

Familia Pacheco Tineo vs. Bolivia. Excepciones Preliminares, Fondo, Reparaciones y CosTAS (2013): Sentencia de 25 de noviembre de 2013. Serie C No 272.

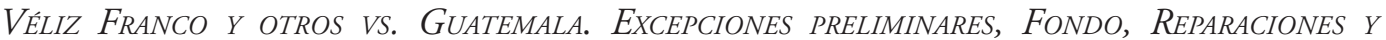
Costas (2014): Sentencia de 19 de mayo de 2014. Serie C No 277.

NORÍN CATRIMÁN Y OTROS (DIRIGENTES, MIEMBROS Y ACTIVISTA DEL PUEBLO INDÍGENA MAPUCHE) VS. Chile. Fondo, reparaciones y Costas (2014): Sentencia del 29 de mayo de 2014. Serie C No 279.

Hermanos Landaeta Mejías y Otros vs. Venezuela. Excepciones Preliminares, Fondo, RePARACIONES Y COSTAS (2014): Sentencia de 27 de agosto de 2014. Serie C No 281.

Defensor de Derechos Humanos y otros vs. Guatemala (EXCEPCIONES PRELIMinares, Fondo, Reparaciones y Costas) (2014): Sentencia de 28 de agosto de 2014. Serie C No 283. 